\title{
Szabolcs-Szatmár-Bereg megye avar sírleletei V. Kora avar kori padmalyos temetkezés Tiszavasvári-Eszenyi-telekröl
}

\author{
'GULYÁS BENCE - ${ }^{2}$ LŐRINCZY GÁBOR \\ ELTE Régészettudományi Intézet, H-1088 Budapest, Múzeum krt.6/B., e-mail: gbence567@gmail.com \\ e-mail: lorinczyg@gmail.com
}

GuLYÁS, B. - LÖRINCZY, G.: Avar finds from Szabolcs-Szatmár Bereg county V. An Early Avar niche-grave from Tiszavasvári-Eszenyi-telek Abstract: In 1960, an isolated grave - dated to the early Avar period - was found in Tiszavasvári, on the plot of Miklós Eszenyi. According to the burial customs (the NEE-SWW orientation of the deceased, the niche grave, the horse skin burial), this grave fits well into the type characteristic of the Early Avar period the Trans-Tisza region. In this article, we examine two parts of the horse harness in detail, i.e. the bone cylinder for fastening the stirrup leather and the omega shaped iron object which was attached to the saddle for fixing the bridle.

Keywords: isolated burial, early Avar period, amphora, bone cylinder for fastening the stirrup leather

\section{Bevezetés}

A Szabolcs-Szatmár-Bereg megyei Tiszavasvári (1. ábra) déli szélén, Eszenyi Miklós telkén, a Vörös Hadsereg - ma Gombás András - út 8. szám alatti telken, ${ }^{1}$ egy pajtán belüli kerek verem kiásása közben, 1960-ban egy amforát és egy jobb felkarcsontot találtak. Előkerülésük idején a település északi szélén, a Dózsa telepen egy szkíta temető feltárásán² dolgozó Lengyel Irina szerzett tudomást, aki jelentette a Magyar Nemzeti Múzeum Adattárának és a nyíregyházi múzeumba Csallány Dezső megyei múzeumigazgatónak. A bejelentést követően az Adattár vezetője, Korek József utasítására és Csallány Dezső felhatalmazásával Gombás András helybeli nyugdíjas tanító - akkor már a nyíregyházi múzeum munkatársa - végezte el a sír hitelesítő

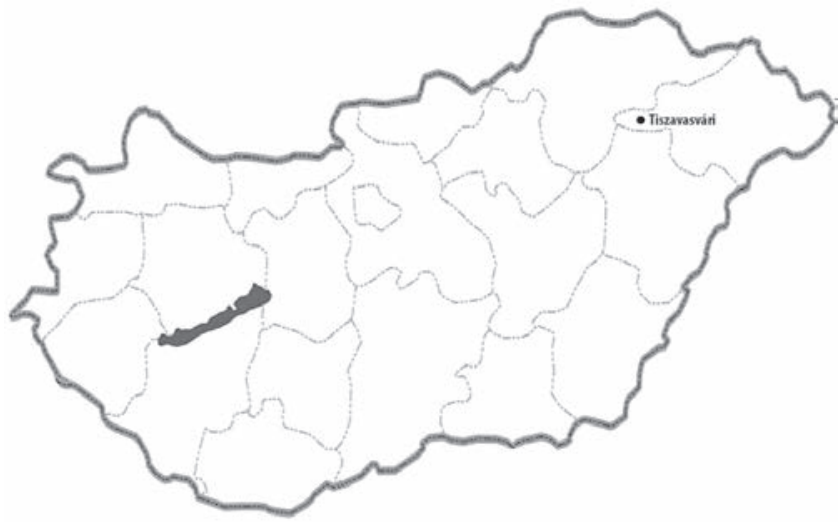

1. ábra. Tiszavasvári elhelyezkedése feltárását a következő évben. Az 1961. november 9-16. között tartó, hét napos ásatás során a veremásás közben az északi sarkánál megbolygatott sírt tárta fel. ${ }^{3}$

A lelőhely a Keleti-főcsatornától kb. 1,5 kilométerre keletre, a környezetéből alig kiemelkedő kisebb magaslat oldalában vagy inkább a lábánál van (2. ábra). Az útra merőleges, keskeny, északnyugat-délkeleti hosszirányú telek délnyugati szélén került elő a sír. A temetkezés környékét Gombás András kutatóárkokkal szinte körbeásatta. Sem ekkor, sem pedig három év múlva, 1964. április 20-23. között folytatott szondázó ásatása során, amikor a sírtól délnyugatra, a szomszédos Róka Imre telkén is kutatóárkokat húzatott, nem került elő újabb sír. A 8 kutatóárokkal a sírtól északkeletre és délnyugatra eső területet vizsgálták át. A pajta északi sarkába ásott kerek verem kialakítása során sem találtak temetkezést (3. ábra 1.). A telek partosabb részén nem lehetett ásatni, mivel azon lakóház és szőlő volt.

1 A sír előkerülési helyeként Csallány Dezső a jelentésében Vöröshadsereg útja 8. számú, Eszenyi Miklós telkét adta meg. A szakirodalomban egyrészt felváltva használták a lelőhely nevét, hol az utca, hol a telektulajdonos nevét adták meg. Ezen kívül keverten, illetve hibásan is hivatkoztak rá a sírból előkerült amfora említése során: Vöröshadsereg útja 8. sír (VIDA 1999, 243.), Tiszavasvári-Koldusdomb, Tiszavasvári (AWAren 1985, Fig. 24.; Avarok 1986, 9. kép; H. TótH - HoRvÁtH 1992, 62, Abb. 16.).

2 Lengyel 1960, 31; Lengyel 1960a, 20.

3 LÖRINCZY 2002, 385. 


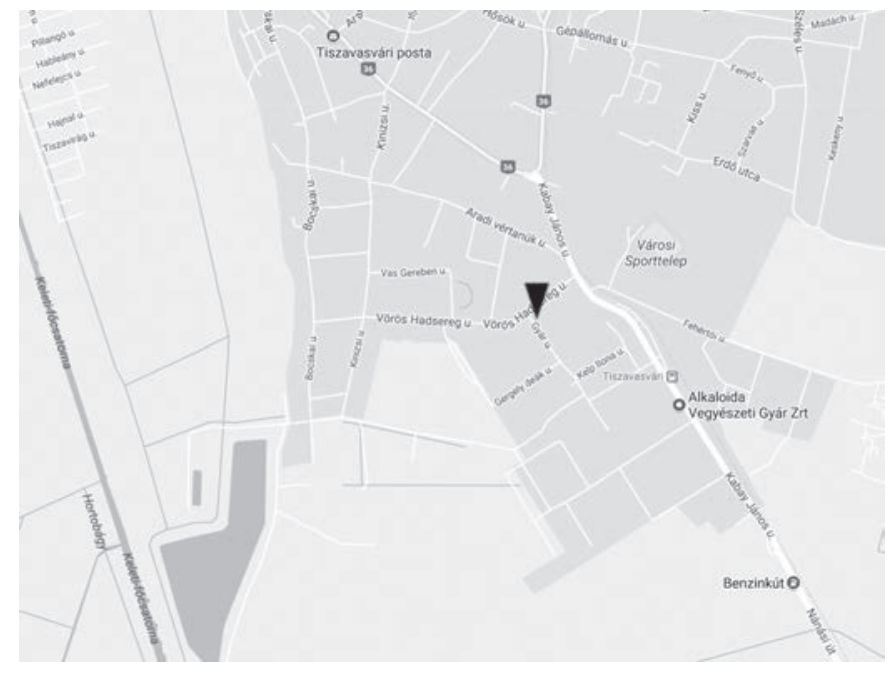

2. ábra. Tiszavasvári belterülete a lelőhellyel
A temetkezés leírása (6. ábra, 7. ábra 1.)

T.: ÉKK-DNyNy. h: 250 cm, sz: 160 cm, m: 230 cm, csvh: 182(?) cm. A sír déli felében, az emberi váz bal oldala mellett egy ló koponyája és lábcsontjai kerültek elő. A sír északi felében egy gyenge csontmegtartású 15-16 év körüli, ${ }^{4}$ - az előkerült leletanyag alapján - feltehetően férfi csontváza hanyatt fekvő, nyújtott helyzetben volt. $A$ váz és mellékletei már a homokrétegbe feküdtek. Az emberi vázmaradványt 1-1,5 centiméter vastagon egészen sötétbarna (feketés korhadék) réteg övezte.

\section{Állatmelléklet és annak leletei:}

1. Egy adultus korú, alacsony, 133,8 centiméter marmagasságú, széles, vastag csontozatú mén ${ }^{6}$ koponyája a sír északkeleti végében, az emberi váz bal vállcsontjától 35 centiméterre, állkapcsával felfele feküdt. A koponyán bronzpatina zöld foltjait lehet megfigyelni. A mellső két lábcsontja a férfi bal combfejétől 40 centiméterre, a hátsó két lábcsont a bal lábfejtől 30 centiméterre feküdt, azokkal hegyesszöget zárva be.

2. Vaszabla töredékes állapotban került elő a ló fogai közül. Elveszett.

3. A lókoponya jobb oldalától 6 centiméterre kerültek elő egy préselt, peremes ezüstveret töredékei, kitöltő masszával és egy ácskapocs alakú bronzhuzallal, illetve egy töredékes szegeccsel (3. ábra 3.). A verettöredék két szélét egy-egy pontkör, középen egy hosszúkás préselt bemélyedés díszíti.

4. Szíjszorító bronzpánt (3.ábra 4.) a lókoponya jobb oldalától 8 centiméterre. Közepén keresztbe egy szegecs van, h: 1,15 cm, sz: $1,5 \mathrm{~cm}, \mathrm{v}: 0,6 \mathrm{~cm}$.

5. L alakú bronzszegecs (3. ábra 7.) a lókoponya jobb oldala mellől.

6. Préselt, peremes ezüstveret ívelt töredéke egy felszerelő szegeccsel (3. ábra 9.) feküdt a lókoponya állkapcsán.

7. Préselt, peremes ezüstveret két töredéke (3. ábra 2.) került elő kitöltő masszával együtt a szemgödör magasságában. A nagyobbik töredéket két pontkör, hosszúkás préselt bemélyedés díszíti. A kisméretű töredék enyhén domború.

8. Három darab P alakú bronzszegecs (3. ábra 8.) került elő a lókoponya végénél, a tarkóvonalnál.

9-10. Téglalap alakú és egy négyszögletes vascsat (3. ábra 5; 4. ábra 3.) került elő a bal mellső lábcsont mellett, a kengyelek közeléből, h: $3,6 \mathrm{~cm}, \mathrm{sz}: 3 \mathrm{~cm}, \mathrm{~h}: 3,5 \mathrm{~cm}, \mathrm{sz:} 3,2 \mathrm{~cm}$.

11. Téglalap alakú vascsat (4. ábra 1.) feküdt a két mellső lábcsont között, h: $3,8 \mathrm{~cm}, \mathrm{sz:} 3,2 \mathrm{~cm}$.

12. Csonthenger (4. ábra 2.) feküdt a bal combnyakcsont külső oldalánál. Teljes belső felületén, illetve a palástja peremének kis felületén vasrozsda nyomok vannak, ${ }^{7}$ ag: $2,3 \mathrm{~cm}$, átm: 2,3 cm.

13-14. Két darab hosszúfülű vaskengyel (4. ábra 5-6.) feküdt a bal combfej külső oldalától 40 centiméterre, a két mellső lólábszárcsonton keresztbe, fülükkel egymás felé fordulva.

15. Egy kisméretű, fordított T alakú vastárgy (4. ábra 4.) került elő a bal bokától a térd felé 5 centiméterre. A felső vége karikában végződik, amiben egy másik vaskarika van füzve. Négyzetes keresztmetszetű szárának teljes felületén, valamint a karika és a T talpának szár felőli oldalán vasoxiddal konzerválódott famaradvány van, mag: $4 \mathrm{~cm}$.

16. Galambtojásnyi ezüsttöredék került elő kitöltő masszával együtt a bal lábszár külső oldalától 35 centiméterre. Elveszett.

17. Három L alakú bronzszegecs (3. ábra 6.) került elő a jobb lábujjcsontoktól 40 centiméterre.

4 A sír embertani anyaga az Embertani Tárba lett felküldve, ahol nincs nyilvántartásba véve. Az antropológiai meghatározás azon a combcsonton alapul, amit a feltárás után 20 évvel, 1983-ban, a lelőhely azonosítása során, özv. Eszenyi Miklósné adott át Lőrinczy Gábornak azzal a megjegyzéssel, hogy a régészek ezt a feltárás során itt felejtették.

5 A leletmentés dokumentációja: JAM Ad. 88.10., 92.35.; a régészeti leletanyagból az amfora JAM 63.975.1., a lócsontok: JAM 63.191.1., 63.501.1-502.2. Itsz. alatt találhatóak. A sír többi lelete leltározatlan.

6 Vörös István meghatározása. Bökönyi Sándor 6-7 év körüli lónak határozta meg (BöKöNYı 1974, 419.).

7 Az ásatási dokumentáció szerint a csontgyưrüvel együtt két darab csontár került elö, ami ma már nem található. Valószínűleg a ló mellső szárkapocscsontjai voltak. 


\section{KORA AVAR KORI PADMALYOS TEMETKEZÉS TISZAVASVÁRI-ESZENYI-TELEKRŐL}

\section{Az emberi váz mellékletei:}

18. A jobb felkarcsont mellett, azzal együtt került elő egy vörös színú, kétfülű bizánci amfora (5. ábra 9.).

Kiváló minőségű, gyorskorongon készített, homokkal és kerámiatörmelékkel soványított, hosszúkás testű, gömbös aljú edény. Felülete finom barázdákkal széles sávban tagolt, nyakának egyik oldalán 6-7 centiméter hosszú vasrozsda folt látható, ${ }^{8}$ mag: $47 \mathrm{~cm}$, átm: $20 \mathrm{~cm}$, ürtartalma: 8,5 liter.

19. A jobb könyök külső oldalától 30 centiméterre egy ovális alakú, négy darabra tört, többrétegű(?) vastárgy feküdt (7. ábra 2.). Restaurálás után a töredékekből egy hosszában ívelt, közel ovális alakú, szélein körbe hiányos vastárgyat ragasztottak össze. Belső, homorú felületének alsó felében, középen, 9 centiméter hosszon, 3-3,5 centiméter szélességben falenyomat látható. Külső, domború felületének 2/3-ad részét vasoxiddal konzerválódott textil takarja. A vászonkötésủ rips szövet vetüléksűrűsége 12, láncsűrűsége 60 darab centiméterenként. A fonalak anyagának megállapítását a fémoxid megakadályozta, ${ }^{9} \mathrm{~h}: 18-19,5 \mathrm{~cm}$, sz: $12-14 \mathrm{~cm}$, mag: $3,5 \mathrm{~cm}$.

20. A bal könyök belső oldalánál három darab ácskapocs alakú felszerelő bronzpánt (5. ábra 2-4.) és egy kalcedon(?). Ez utóbbi elveszett, h: $3,8 \mathrm{~cm}, 1,5 \mathrm{~cm}, 1,7 \mathrm{~cm}$.

21. Kerek vascsat (5. ábra 7.) feküdt a két szeméremcsont között, átm: $3,1 \mathrm{~cm}$.

22. Egyenes, egyélű vaskés töredéke (5. ábra 5.) feküdt a két szeméremcsont között. Egyik oldalán vasoxiddal konzerválódott bőrmaradvány van, h: $4,3 \mathrm{~cm}, \mathrm{sz:} 1,5 \mathrm{~cm}, \mathrm{v}: 0,2 \mathrm{~cm}$.

23. Szürkésfehér színú kova (5. ábra 6.) és egy darab, két síkban meghajlított bronzláncszem töredékes állapotban (5. ábra 1.) került elő a két szeméremcsont között.

24. Préselt bronz szijvég feküdt töredékes állapotban a baloldali szeméremcsont előtt. Elveszett.

25. Egyélű vaskés feküdt a bal combcsont külső oldalától 20 centiméterre. Elveszett.

26. Elhegyesedő végű, kerekátmetszetű vasszerszám(?)töredékei (5.ábra 8.) kerültekelő a bal lábszár alatt keresztbe, a bal boka felett és alatt. A tárgy felületén szerves anyag (fa, textil, bőr) maradványa nem látható, h: $15,5 \mathrm{~cm}$.

27. A bal bokacsont alatt 5 centiméterre egy kisméretű vastárgy került elő, amely elveszett.

28. Két darab, nagyjából L alakú, meghatározhatatlan vastárgy (a sírlapon kard, csákány stb. felirattal) került elő a jobb lábfej csontjai előtt, illetve a külső oldala mellett. Elvesztek.

\section{A temetkezési szokásokról}

\section{A magányos temetkezésröl}

A sírt egy verem ásása közben találták, és a feltárását követő évben a sír környékén húzott kutatóárkos ásatás során újabb temetkezés nem került elő (3. ábra 1.). Se a telek tulajdonosa, se a szomszédjaik nem tudtak arról 1983-ban, hogy telkeiken, vagy azok előtt, a partosabb területen haladó út, és az út menti árok kialakítása közben, illetve a páratlan számú házak építése során sírok, állati maradványok kerültek volna elő. ${ }^{10}$ Ezek alapján feltételezhető, hogy ebben az esetben egy magányos temetkezéssel kell számolnunk. ${ }^{11}$

Kora avar kori magányos sír viszonylag gyakori a Tiszántúlon, mivel eddig összesen 13 olyan lelöhely ismert, ahol ilyen típusú temetkezés ásatáson került elő, és nagy a valószínúsége annak, hogy ezeken a helyszíneken több sír nem volt. Három másik lelőhely esetében ezt a helyzetet hitelesítő ásatás is alátámasztotta. ${ }^{12} \mathrm{~A}$ Tiszántúl mellett még a Kisalföldön, valamint a Duna-Tisza-közén számolhatunk a magányos temetkezések gyakoribb előfordulásával. ${ }^{13} \mathrm{~A}$ jelenség magyarázatául számos elképzelés született: ezek a sírok a pásztorkodó életmóddal lennének összefüggésbe,,$^{14}$ felhagyott temetőkezdemények ${ }^{15}$ vagy a vezető réteg egy-egy tagját ${ }^{16}$ rejtik. Mivel azonban ezek a temetkezések az egész kora avar korban fellelhetők, valamint területileg a Tiszántúl egészén előfordulnak, értelmezésükre nem adható egységes magyarázat. ${ }^{17}$

8 A rozsdafolt valószínúsíti, hogy az amfora a sírban a jobb felkar mellett feküdt, mivel egyrészt azzal együtt került elő, másrészt a rozsdafoltot okozó vastárgy valószínúleg a jobb könyök mellett előkerült, eddig ismeretlen vastárgy okozhatta.

9 A textilvizsgálatot és a meghatározást T. Knotik Márta végezte el.

10 Az elő nem került sírok lehetséges magyarázata lehet a padmalyos sír nagy mélysége. Ha hasonló volt a környéken, azt földmunka biztosan nem érintette. De a kutatóárkokban kirajzolódó sírfolt elszíneződését Gombás András biztosan észrevette volna.

11 Nem zárhatjuk ki annak lehetőségét, hogy egy temetési terület - mint amilyen pl. a Kashalom-dülőből ismert LöRINCZY - RÁcZ 2014, 166-167. -, egymástól távol fekvő temetkezései közül került elő itt egy. De ezt csak egy újabb temetkezés előkerülése igazolhatja.

12 GuLYÁs 2013, 21; LÖRINCZY - RÁCZ 2014, 64. lj.

13 TOMKA 2005; BALOGH 2016, 31-34.

14 LÖRINCZY 1996, 184; TOMKA 2005, 161.

15 ТОМКА 2008, 238.

16 LÁSZLó 1976, 104

17 LÖRINCZY 1998, 351; LöRINCZY - RÁCZ 2014, 171. 


\section{A sír tájolása}

Az ÉKK-DNyNy-i irány, ami voltaképp ÉK-DNy-iként is értelmezhető irányítás, a kora avar kori tiszántúli temetkezésekre jellemző, és domináns a Tiszavasvári környéki temetkezések esetében is. ${ }^{18} \mathrm{~A}$ mai SzabolcsSzatmár-Bereg megye területéről ettől eltérő tájolású (É-D-i és Ny-K-i) kora avar kori temetkezések is ismertek, ezek talán eltérő eredetű népesség megtelepedésére utalnak. ${ }^{19}$

\section{A padmalyos sírforma}

Bár nincs egyértelmú megfigyelés és dokumentáció a sírformára vonatkozóan, több adat is arra utal, hogy a sír eredetileg padmalyos temetkezés volt. Ilyen a sírnak az átlagos aknasírnál nagyobb, 160 centiméteres szélessége. A sír hosszúságánakés szélességének arány ${ }^{20} 1,6$, ami jelentős mértékben eltér a közeli Tiszavasvárikoldusdombi sírok 2,6-os és 3,7-es arányától. ${ }^{21}$

Az állkapoccsal felfele előkerült lókoponya helyzete arra utal, hogy a padmaly szájának beszakadása után a sír aknarészén kialakított padkán fekvő lókoponya a padmaly irányába bedőlt. E mellett a sematikus ásatási sírrajzon ábrázolt lólábcsontok mintha a férfiváz felé dőlnének, ami szintén erre a helyzetre utal.

A Tiszántúlról mára mintegy 20 lelőhelyről ismerjük a padmalyos sír formáját, két nagyobb temető esetében 60-90 padmalyos temetkezést. ${ }^{22}$ A tiszántúli sírok kialakításukat tekintve meglehetősen egységes képet mutatnak: a padmalyt mindig az akna északi, északnyugati oldalába vájták, a legtöbb esetben az aknától mélyebbre, ahogy az Eszenyi-telken feltárt sír esetében is ez történt. ${ }^{23}$

A Körösöktől északra az Eszenyi-telki síron kívül csak két padmalyos temetkezést ismerünk: HajdúdorogVároskert u. 1. sír és Kaba-Belterület. De ezekben az esetekben a halott számára kialakított üreget az ellenkező oldalon alakították ki. ${ }^{24}$ Ez a két sír a sajátos temetkezési szokásaival a kora avar kori Tiszántúlon az általánostól eltérő kulturális közeget képvisel.

A tiszántúli kora avar kori padmalyos temetkezések a fülkesíroktól eltérő elterjedést mutatnak. Míg az előbbiek a régió egészén egyenletesen, addig az utóbbiak a Tisza-Körös-Aranka közén kerültek elő. ${ }^{25}$

A kiemelkedően nagyméretű sírnak volt egy, a felszínen sokáig látható következménye. A 220 centiméter mély, 250 centiméter hosszú és 160 centiméter széles temetkezés 80 centiméter széles aknarészének a térfogata kb. 4,4 m³, a sír oldalában vájt padmalyé (35-40 centiméter magas boltozattal számolva) hozzávetőlegesen $3 \mathrm{~m}^{3}$ lehetett. A sírból kitermelt több mint $7 \mathrm{~m}^{3}$ földből - a padmaly lezárása és az aknában elhelyezett részleges lómaradvány és nyereg térfogatigénye miatt - több mint $4 \mathrm{~m}^{3}$ föld a temetés során kimaradt. Ez a földmennyiség nem egy sírhantot, hanem egy kisebb halmot képezett a sír felett. Ehhez még figyelembe kell azt is venni, hogy a temetés idején kitermelt föld laza szerkezetú volt, tehát nagyobb térfogattal rendelkezett, mint eredeti helyzetében. ${ }^{26}$

\section{A vájt koporsó}

A Kárpát-medence klimatikus viszonyai mellett nagyon kevés esély van a koporsók közvetlen előkerülésére, egykori meglétükre egyéb bizonyítékok utalnak. Ilyen például a koporsókapcsok előfordulása, melyek szórványosan a régiónkból, például Tiszavasvári-Koldusdomb 23. sírból és Hajdúdorog-Városkert utca 1. sírból ismertek. ${ }^{27}$

A kora avar kori Tiszántúlon sokkal gyakoribbak - mondhatni általánosak - a vájt vagy rönkkoporsóra utaló, a csontváz körül megfigyelhető sötétebb, pár centiméter vastag elszíneződés, az eltérő - koporsón belüli és kívüli - sírbetöltés stb. ${ }^{28} \mathrm{Az}$ itt bemutatott sírban az emberi váz körül lehetett a koporsó szélét dokumentálni. Ez a koporsótípus a Nyíri-Mezőség területéről Tiszavasvári-Kashalmi-dűlő 33. sírból és Tiszaeszlár-BashalomCsengőspart 2. sírból, ${ }^{29}$ míg Hajdú-Bihar megye területéről Ártánd-F 142/1 határkö ${ }^{30}$ és Biharkeresztes-Lencséshát ${ }^{31}$ lelőhelyekről ismertek.

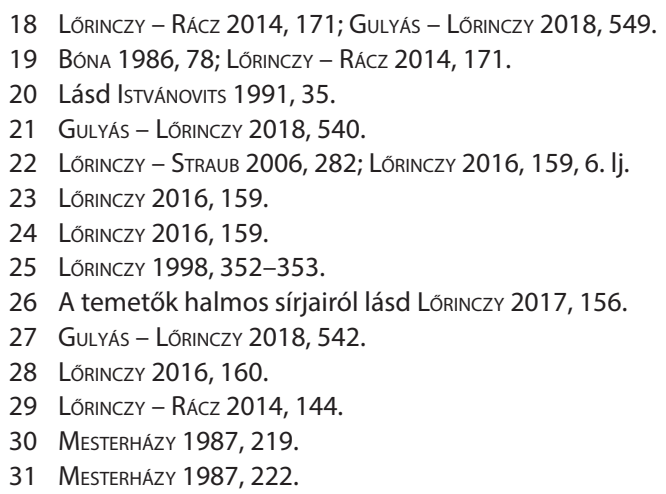




\section{KORA AVAR KORI PADMALYOS TEMETKEZÉS TISZAVASVÁRI-ESZENYI-TELEKRŐL}

Meg kell azonban jegyeznünk, hogy valószínüleg a régebbi ásatásokon is gyakrabban kerültek elő a vájt koporsóra utaló elszíneződések, de nem fordítottak kellő figyelmet annak dokumentálására.

\section{A részleges lovastemetkezés}

A kora avar kori tiszántúli temetkezések egyik legjellemzőbb melléklete a részleges állattemetkezés: ló, szarvasmarha, juh és kecske egyaránt került a sírokba. ${ }^{32}$ Ahogy azt az itt ismertetett sír is mutatja, a tágabb régió 7. századi temetkezései esetében egy sajátos nyúzási módot lehetett dokumentálni: a csuklóizület fölött az állat orsó- és a sing-csontját kb. az alsó harmaduknál ferdén kettéhasították, majd ezeket, valamint a koponyát a bőrben hagyva az állat maradványát a sírba helyezték. ${ }^{33} \mathrm{~A}$ Tiszavasvári határából ismert lelőhelyek esetében a részleges lovastemetkezés általánosnak mondható, Koldusdomb 24 sírjából nyolc, ${ }^{34}$ míg a Kashalmi-dűlő hat temetkezése közül egy ${ }^{35}$ tartalmazott ilyen maradványokat.

A részleges lovastemetkezés során a ló maradványait általában felszerszámozva (zabla az állkapcsok között stb.) temették el.

Ahogy az előbb említettük, a tiszántúli kora avar kori sírokban nem csak lovakat, hanem nagy- és kiskérődző állatok viszonylag nagyszámú maradványait is mellékelték. Elég utalnunk a nem messze fekvő koldusdombi temető sírjainak „állatbőségére". ${ }^{36}$ Ennél a temetkezésnél azonban csak ezen állatmellékletek hiányát regisztrálhatjuk. Pedig a sír nagy mérete, formája és az elhunyttal eltemetett bizánci amfora, a lószerszámzat ezüstveretei alapján elvárható lenne itt is a gazdag állatmelléklet. Akárcsak az Eszenyi-telki sírtól alig 2,5 kilométerre előkerült Tiszavasvári-Kashalmi-dűlő 34. sír esetében, ${ }^{37}$ ahol a szintén gazdagnak mondható régészeti leletanyag mellett a temetkezésből csak egy részlegesen eltemetett ló felszerszámozott maradványa került elő. $E$ két temetkezéssel szemben igen gazdag állatmellékletek kerültek elő a tiszavasvári-koldusdombi ${ }^{38}$ és a tiszavasvári-utaséri-dűlői ${ }^{39} 7$. századi avar temető sírjaiból.

\section{Az edénymelléklet}

Az amforát még a temetés előtt fektették le a padmaly belső fala mellé. Fektették, és nem állították ${ }^{40}$ mert a padmaly belmagasság nem valószínú, hogy a fél métert meghaladta volna, főleg nem annak belső fala mentén. Valószínúleg az amfora előtt helyezték el a vaslemezből kalapált mellékletet (7. ábra 2.), mert csak ez okozhatta az amfora nyakán látható, az edény tengelyével párhuzamos 4,5-5 centiméter hosszú, 2-2,5 centiméter széles vasrozsda elszíneződést. ${ }^{41} \mathrm{Az}$ amfora mellé helyezték a férfi koporsóját. A sír megtalálása során az előkerült amforával együtt a mellette fekvő fiatal jobb felkarcsontját emelték ki a sírból.

A Tiszántúl mintegy 100 kora avar kori lelőhelyéről összesen kb. 250 edényt ismerünk, ami alapján nagyjából minden ötödik sírba helyeztek kerámiát. ${ }^{42}$ Ez sokkal nagyobb arány, mint ahogy a kora avar kori Kárpát-medence más területein megfigyeltek. Az edények túlnyomórészt a koponya körül találhatóak, csak igen ritkán kerülnek elő a láb mellől. Az Eszenyi Mihály telkén előkerült amfora nemcsak típusában egyedülálló a Tiszántúlon, hanem a sírban elfoglalt helyében is. A tiszántúli kora avar kori sírok döntő többségében a fej mellé helyezték az edényeket, ${ }^{43}$ a padmalyos temetkezések esetében szinte mindig a koponya bal oldala mellett kerülnek elö. Ez arra utal, hogy az elhunyt koporsóját becsúsztatva a padmalyba ezt követően tették a kerámiaedényt a koporsó fej körüli végéhez.

Az amfora eredetileg minden bizonnyal bor tárolására szolgált. ${ }^{44}$ Ezzel szemben a sírokba helyezett edények sírbeli funkciója nem egyértelmú, mert temetés során folyadék/ital mellett ételt vagy akár virágot ${ }^{45}$ is tehettek bele.

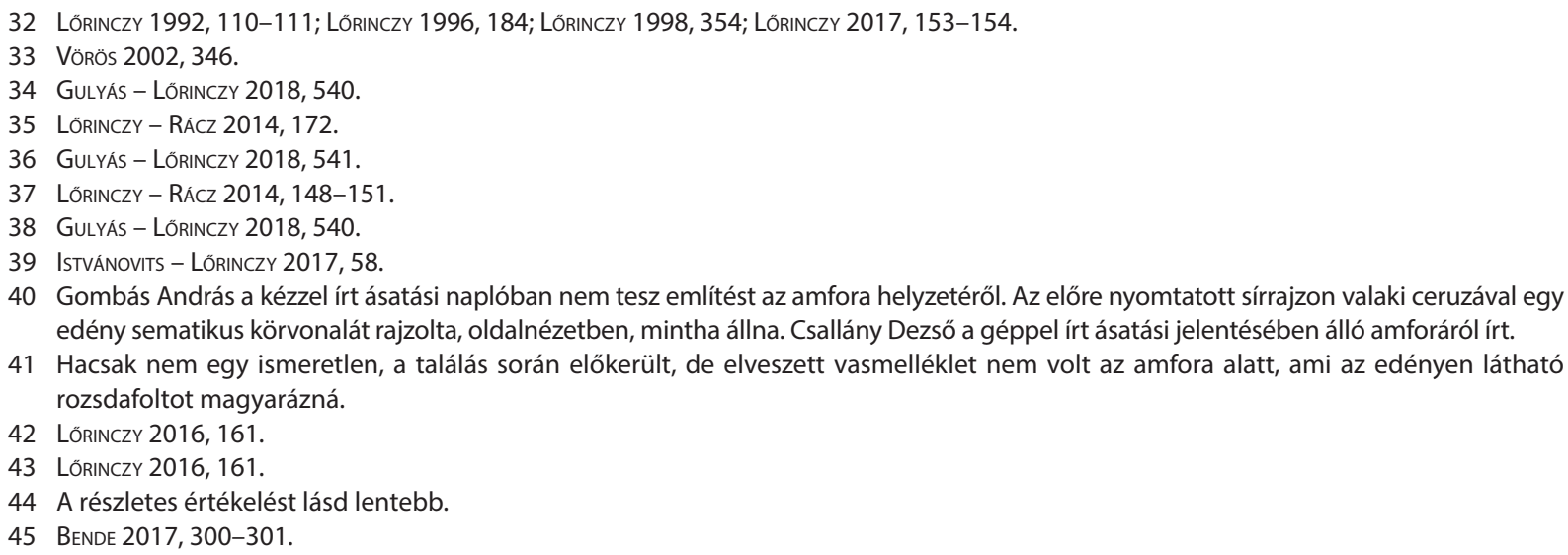




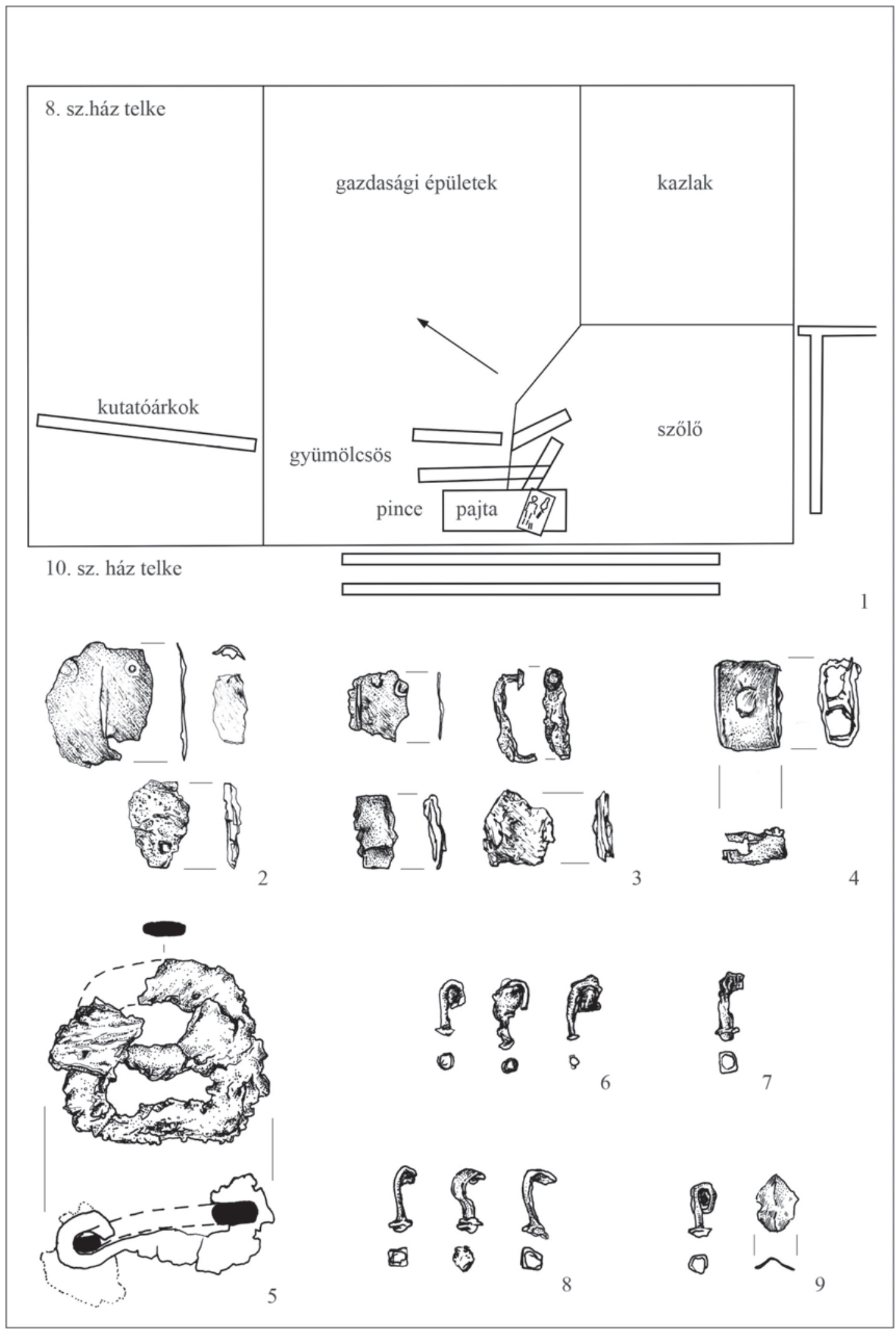

3. ábra. Tiszavasvári-Eszenyi M. telke. 1. A telek beosztása a kutatóárkokkal; 2-9. Leletek a sírból. M:2-9: 1:1 


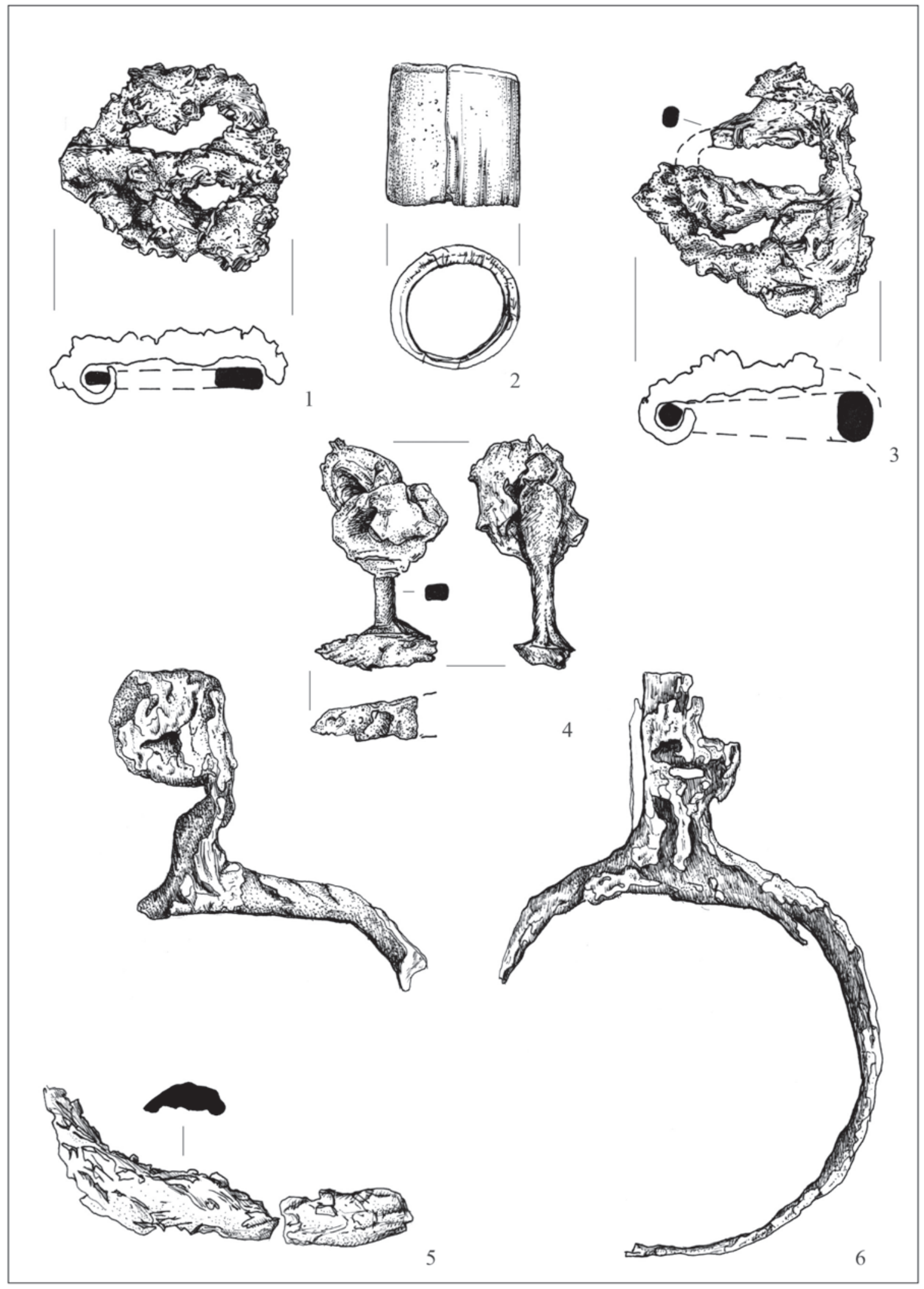

4. ábra. Tiszavasvári-Eszenyi M. telke. 1-6. Leletek a sírból. M: 1-4: 1:1, 5-6: 1:2 


\section{Az anyagi kultúra elemei}

\section{A lószerszámzat részei}

Zabla. A töredékesen elökerült és elveszett zabla típusa nem állapítható meg. A Körösöktől északra fekvő területen föleg az aszimmetrikus kialakítású, csuklós csikózablák használata volt általános a kora avar korban. Kis számban kerültek elő oldalpálcás zablák is. A kashalmi 34. sírban fa oldalpálca maradványait figyelték meg, míg Hajdúdorog-Városkert u. 1. sírban a fa vagy szaru zablapálcát ónlemezzel vonták be. ${ }^{46}$

Lószerszámveretek. A ló koponyája környékén préselt ezüstlemezek mára már nem rekonstruálható töredékei helyezkedtek el, melyek a fejkantárt díszítették. A legnagyobb töredéken függőlegesen egy borda fut végig, mely szimmetrikusan osztja ketté a veretet. Ennek két oldalán egy-egy préselt motívum figyelhető meg, a jobb oldali pontkör díszítésű, a bal oldali nem határozható meg pontosan. Látszólag ez az elrendezés egy arcot is ábrázolhat, ahogy az a jutasi 166. sír maszkos övveretén is látható. ${ }^{47} \mathrm{~A}$ megmaradt töredék alapján a tárgy mintázata nem rekonstruálható, így nem dönthető el egyértelműen, hogy a lemezen emberi arcot ábrázoltak. Ha a vereten sematikus arcábrázolás van, az annyiban egyedülálló, hogy a kora avar kori leletanyagban eddig nem ismerünk ilyen ábrázolást lószerszámvereten.

A sírból nyolc darab P alakú, általában kerek veretek rögzítésére szolgáló felszerelő bronzszegecs is előkerült, melyek végén négyzetes alátétlemezek vannak. Ez a szegecstípus a kora avar korban széles körben elterjedt, rozetták (pl. Csákberény-Orondpuszta 395. sír, Környe 124. sír) ${ }^{48}$ illetve félgömbös lószerszámveretek (pl. Zamárdi-Réti földek 34. és 580. sír) ${ }^{49}$ szíjra rögzítésére használták. Az 580. sír félgömbös vereteinek oldalnézeti rajza alapján a szegecs kiszélesedő fejét a veret hátulján lévő masszába nyomták, majd a szegecset a bőrön átnyomták, és a végére helyezték az alátétet. Ezek alapján feltehető, hogy félgömb alakú, préselt ezüst lószerszámveretek is díszítették a szíjazatot.

Nyereg vas szíffeszítője. A kisméretű, fordított T alakú, felül karikában végződő vas szíffeszítő50 (4. ábra 4.) egy kevésbé látványos, de a lovasfelszerelés egyik sajátos szereléke, amely mindeddig kevés figyelmet kapott. A kisszámú - de egyre gyarapodó - publikált párhuzamainak ${ }^{51}$ nagy többsége nyújtott $\Omega$ alakú, feje ritkán négyzetes kialakítású, szárainak végeit két, ellentétes irányban kihajlították. Az Eszenyi-teleki példány legközelebbi párhuzama Tiszavasvári-Koldusdomb 1. sírjából ${ }^{52}$ került elő. E két temetkezésen kívül a tiszántúli kora avar kori publikált anyagból még Békésszentandrás-Benda-tanya $87 .{ }^{33}$ és Szegvár-Oromdűlő 100 . sírjából ${ }^{54}$ ismerjük a szíjfeszítő analógiáit.

A nyereg ezen szerelékének a használata tovább élt, és ezt az avar kor második felében ugyanerről a területről az alábbi temetkezések leletei igazolják: Pitvaros-Víztározó 125. sír, ${ }^{55}$ Szarvas-68. lelőhely 156. sír, , $^{56}$ Székkutas-Kápolna-dúlő 239. és 466. sír, ${ }^{57}$ Székkutas-Új Élet Tsz 4. sír, ${ }^{58}$ Szarvas-Grexa téglagyár 156. és 376. sír, ${ }^{59}$ Szarvas-Kovácshalom 40. sír.60

Ez utóbb felsorolt sírok döntő többsége lószerszámos temetkezés volt, azaz az elhunyt mellé nem a lovat, hanem csak annak szerszámzatát helyezték el a temetés során. Ezzel szemben a kora avar kori tiszántúli temetkezések között részleges, egész lovas és lószerszámos temetkezést egyaránt találunk. De a nyergeket a dunántúli avar lovasok is felszerelték vas szíjfeszítővel, amint azt - a teljesség igénye nélkül - az alábbi sírok leletei bizonyítják: Környe 129. lósír, ${ }^{61}$ Zamárdi 1634. lósír, ${ }^{62}$ és Komárom-Hajógyár 103. lovassír. ${ }^{63}$

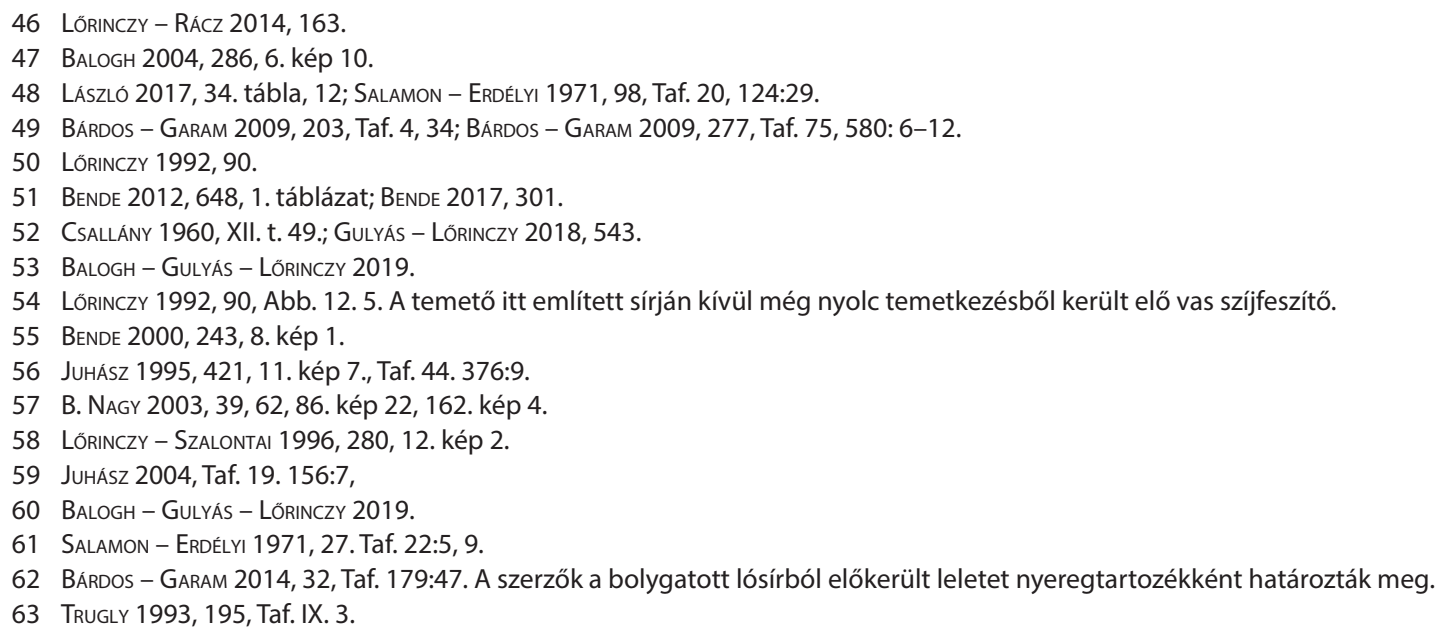




\section{SZABOLCS-SZATMÁR-BEREG MEGYE AVAR SÍRLELETEI V. KORA AVAR KORI PADMALYOS TEMETKEZÉS TISZAVASVÁRI-ESZENYI-TELEKRŐL}

A fentiek mellett a szíjfeszítők általános ismeretét és használatát az erdélyi Baráthely (ma: Bratei, Románia) 3. temető 19. és 108. kirabolt lósírjából előkerült példányok is illusztrálják. ${ }^{64}$

Ezeknek a nyeregszerelékeknek korszaktól, helytől függetlenül több közös jellemzőjük is van. Formájuk lehet kulcs, fordított T és nyújtott $\Omega$ alakú, maximális hosszuk 3-4 cm között van, rövid száraiknak a felületét mindig vasoxiddal konzerválódott famaradvány borítja. Hiteles megfigyelések szerint mindig a kengyelekkel, hevedercsatokkal együtt, azok közelében kerültek elő. A fanyereg talpába süllyesztett tárgy bőrszíj vezetésére, annak megfeszítésére szolgált. ${ }^{65}$

Hosszúfülü kengyelpár. Tiszavasvári kora avar kori lelőhelyeiről - a viszonylag nagyszámú lovastemetkezés ellenére - kevés kengyelt ismerünk. A kashalmi 34., és a koldusdombi 21. sírból egy hurkosfülű kengyelpár, míg utóbbi temető 1 . sírjában egy hurkos- és egy hosszúfülü kengyel került elő. ${ }^{66} \mathrm{~A}$ hosszúfülű kengyelek a Nyíregyháza területén található lelőhelyeken összpontosulnak, ilyeneket találtak Nyíregyháza-Moszkva utca, Nyíregyháza-Városi Kertészet 1936/3. sír és az 1937. évi temetkezésben is. ${ }^{67}$ Bár ezeknek a kengyeleknek a kora avar koron belül nincs keltező értékük, de az eddig megfigyeltek alapján a vaskengyel sírba helyezése a Tiszántúlon viszonylag kései jelenség, a 7. századnál korábbra nem keltezhető. ${ }^{68}$

Kengyelszij szorító csonthenger. A fiatal férfi bal combnyakjának külső oldala mellett feküdt egy rövid csonthenger (4. ábra 2.). Teljes belső felületén, illetve palástja peremének kis területén vasrozsda nyomai figyelhetőek meg. Az elöre nyomtatott sírlap szerint a csontgyürühöz legközelebb - a három vascsaton kívül - a két hosszúfülü vaskengyel feküdt a bal combfejtől kb. 40 centiméterre, fülükkel egymás felé, de a csontgyűrütől ellenkező irányba.

Ismereteink szerint tiszántúli kora avar kori sírból legelőször a szentes-derekegyházi-oldali lovassírból került elő hasonló darab. ${ }^{69} \mathrm{~A}$ sírban fekvő férfi bal lábszárcsontjának külső oldala mellett, részben egymáson fekvő, részben elporladt hurkos fülű kengyelpár fülei mögött feküdt a csonthenger a palástján, a kengyel (és a fül) tengelyének vonalában. ${ }^{70}$

A szentesi példánnyal megegyező darab került elő a Gyoma 264. lelőhelyen feltárt 3. sírból, egy 22-28 éves korában elhunyt nő felett 10 centiméterre, azzal azonos tájolásban fekvő részleges lótemetkezés mellékleteként. A részben bolygatott sírból a rövid csonthenger a lócsontok fektetési szintjén, a jobb mellső lábcsont mellett került elő. ${ }^{71}$ A vas kengyelpár ugyancsak a ló fektetési szintjén, de a nő jobb felkarcsontja felett, annak két oldalán feküdt.

A mokrin-vodoplav-dűlői (Szerbia) 67., padmalyos ${ }^{72}$ sírját a feltáró Szasszer János tanító részletesen leírta. ${ }^{73}$ Ezek szerint a sír déli felében fekvő teljes lócsontváz bal oldali kengyelének szíjvégénél (fülénél) egy 3 centiméter hosszú henger alakú csonttárgy feküdt. ${ }^{74}$

A tárgy funkciójának meghatározására már a szentes-derekegyházi példány előkerülése és dokumentálása alkalmat adhatott volna, ha Csallány Gábor a tényekből indul ki. A csonthenger kengyelfül mögötti, ahhoz igen közeli helyzete és azzal egyvonalban való fekvése alapján adódhatott volna a logikus következtetés, hogy a csonthenger a kengyelekkel, illetve azok szíjazatával függhet össze. Ezzel szemben Csallány Gábor Cs. Sebestyén Károly felvetésére hivatkozva - az íjászfelszerelés részének gondolta és ijászgyűrüként határozta meg. ${ }^{75} \mathrm{~A}$ gyomai sír publikálója nem volt olyan szerencsés helyzetben, mint Csallány Gábor, mivel a sír azon része, ahol a csonthenger előkerült, bolygatott volt. De mivel a lótemetkezés szintjén feküdt a csonthenger, ezért logikusan következtetett arra a szerző, hogy ugyan a közelebbi felhasználási módja nem egyértelmű, de feltehető, hogy az a lószerszámzat része volt.76

64 BÂRZu 2010, Taf. 6. G. 19:5, Taf. 19, G. 108:2a.

65 Ne tévesszen meg bennünket az itt felsorolt sírok kevés száma. Ennél jóval gyakoribb lehetett a szíjfeszítők használata, mert a publikált példányok döntő többsége hiteles körülmények között, régészeti feltáráson került elő. Nagy a valószínűsége, hogy a régi feltárásokon ezek a leletek összetörtek, elkallódtak. Az elmúlt évtizedekben feltárt temetők lovassírjaiból valószínűleg nagyobb számban kerültek elő és lesznek majd ismertek ezeknek a temetőknek a publikálása során.

66 GULYÁs - LÖRINCZY 2018, 531.

67 LÖRINCZY - RÁCZ 2014, 165.

68 LóRINCZY 1996, 185; LÖRINCZY 1998, 351.

69 CSALLÁnY 1939, I. tábla 6, II. tábla 16-17, I. tábla B 17-19.

70 Már amennyiben ezt a fotó (CSALLÁnY 1939, I. tábla A) alapján meg lehet pontosan határozni. A kengyelek és a csonthenger sírbeli helyzetét eredetinek fogadjuk el annak ellenére, hogy a sír egyes leletei és az állatcsontok közül több is - bizonyára a sír fotózása miatt - vissza lettek a sír aljára fektetve.

71 Sомоgrı 1997, 99, 6. kép 5.

72 LÖRINCZY - StRAuB 2006, 288.

73 MFM Régészeti Adattár 1577-93., 1578-93., 1579-93. Itsz.

74 A csonthengert a sírleírásban (BALOGH 2004, 268-269.) nem említik, de a sír leletanyagának katalógusában szerepel (RANISAVLev 2007, 23, Tab. 27:9.).

75 CSALLÁNY 1939, 116

76 SOMOGYI 1997, 101. 


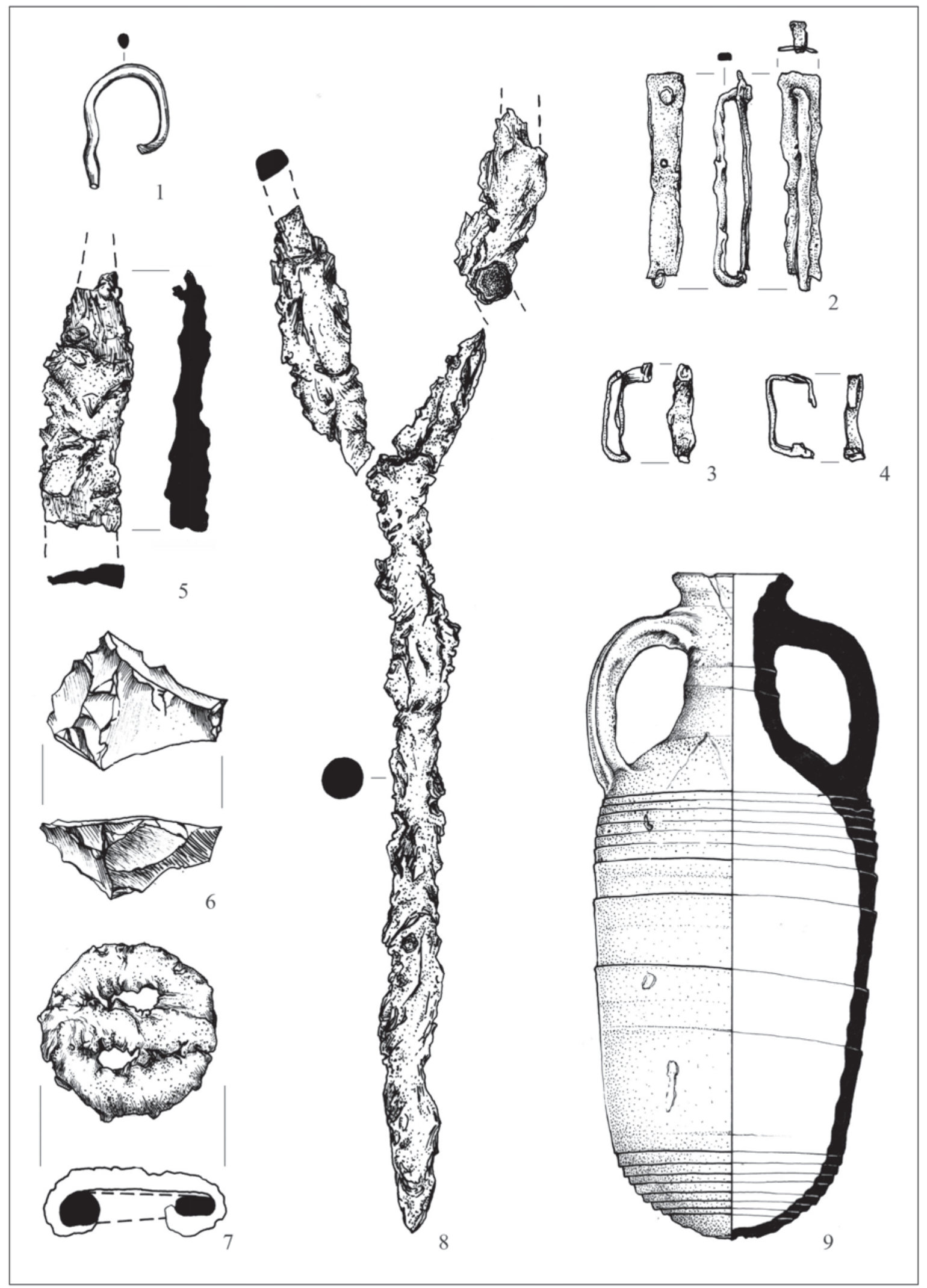

5. ábra. Tiszavasvári-Eszenyi M. telke. 1-9. Leletek a sírból. M: 1-8: 1:1, 9: 1:4 


\section{SZABOLCS-SZATMÁR-BEREG MEGYE AVAR SÍRLELETEI V. KORA AVAR KORI PADMALYOS TEMETKEZÉS TISZAVASVÁRI-ESZENYI-TELEKRŐL}

A szentes-derekegyházi példány alapján tett következtetésünket a mokrini 67. sír kengyelének és csonthengerének sírbeli helyzete is valószínűsíti. A Tiszavasvári-Eszenyi-telken előkerült példány belső falán megfigyelhető vasrozsda nyomok a kengyel és a csonthenger kapcsolatát tovább erősítik.

A még publikálatlan szegvár-oromdűlői temető négy sírjából került elő gímszarvas agancságából ${ }^{77}$ faragott csonthenger. Ezekre a darabokra jellemző, hogy a sírban a kengyel fülén, vagy közvetlenül a fül mellett, illetve mögötte 2-3 centiméterre feküdtek, valamint a tiszavasvári példányhoz hasonlóan több szegvári csonthenger belső falán vasoxid összefüggő foltja látható.

A fentiek alapján igazoltnak látjuk, hogy a Tiszántúlon előkerült csonthengerek funkciója - sírbeli helyzetük és leletösszefüggésük alapján - a vaskengyel szíjazatának a fülön vagy közvetlenül a kengyelfül fölötti összeés leszorítása volt. Ezeknek a csonthengereknek a hossza 2,3-3,2 centiméter, külső átmérője 2,2-3 centiméter, míg belső átmérője 1,5-2 centiméter között változik. ${ }^{78}$

Azonban a kengyel szíjazatát leszorító csonthengerek nem csak a Tiszántúl kora avar kori temetkezéseiből, hanem a dunántúli kora avar kori sírokból is ismerünk a teljesség igénye nélkül: Budapest-Csepel-Háros 96. sír, ${ }^{79}$ Budapest-Szőlő köz 28. sír, ${ }^{80}$ Komárom-Hajógyár 103. lovassír, ${ }^{81}$ Kölked-Feketekapu A 474. sír, ${ }^{82}$ KölkedFeketekapu B 135. sír, ${ }^{83}$ Környe 129. sír, ${ }^{84}$ Pókaszepetk-Mesterföldek 13. és 168. sír, ${ }^{85}$ Zamárdi-Réti földek 1406. sír. ${ }^{86}$ Ezutóbbi síregyüttesben előkerülttcsonthenger mellett a hasonló funkciót betöltő téglalap keresztmetszetú vaspánt már átvezet bennünket a vas szíjszorítós pántok típusához. llyeneket említhetünk Zamárdi-Réti földek 73., 348., 455. és 511. sírjából. ${ }^{87}$

Az erdélyi Baráthely 3. temetőjének 19. és 27. számú lósírja is tartalmazott egy-egy csonthengert. ${ }^{88}$ Míg a 19. sír a rablás következtében teljesen fel volt dúlva és a lócsontok hiányosan, bolygatott helyzetben feküdtek a maradék leletekkel együtt, ${ }^{89}$ addig a 27. lósír in situ állapotban maradt meg. ${ }^{90}$ Ebben a sírban a bal oldali kengyel fülétől alig 2-3 centiméterre feküdt az enyhén kúpos csonthenger. Ez alapján írhatta a szerző, hogy ezek a csonthengerek kapcsolódhattak a kengyelhez. ${ }^{91}$

Bár az itt felsorolt temetkezések döntő többsége kirabolt, bolygatott lósír volt, ennek ellenére sok esetben a ló mindkét oldalán a kengyelfülek közelében kerültek elő a csont és vas szíjszorítók. Így nem véletlen, hogy a csonthengereket tartalmazó sírok egyes publikálói - Nagy Margit és Garam Éva - minden indoklás, magyarázat nélkül szíjbújtatónak határozták meg őket.

Ezek a rövid csonthengerek és vaslemezből hajlított, téglalap keresztmetszetú vaspántok nem szíjbújtatók a szó hagyományos értelmében, ${ }^{92}$ hanem szíjfeszítők voltak. Ha bújtatók lettek volna, akkor ezek nem feltétlen a kengyelfül közelében, rajta vagy közvetlenül mellette kerülnekelö, hanem a kengyel függesztő szíjazatának változó magasságában. Ugyanakkor a bújtató a függőlegesen lógó szíjon - saját súlyánál fogva is -, lovaglás közben a rázkódástól lecsúszhatott volna. Pedig a szíjfeszítő funkció éppen az volt, hogy a kétágú kengyelszíjat szorosan össze- és hozzászorítsa a kengyelfülhöz, így akadályozva meg a kengyelszij végén a vaskengyel mozgását.

A megegyező funkció mellett - bár jelen pillanatban kis esetszám áll a rendelkezésünkre - több eltérés is tapasztalható a Dunától nyugatra, illetve a Tiszántúlon előkerült csont kengyelszífeszítókkel kapcsolatban. Míg a tiszántúli temetkezésekből mindig csak az egyik kengyel mellől kerül elő csonthenger, addig a dunántúli sírokban általában mindkét kengyel mellett előfordult.

77 Vörös István meghatározása.

78 A kézirat lezárása után jutott tudomásunkra, hogy Tiszaderzs-Szentimrei úti lelőhelyen (MADARAS 2002, 378.) 1937-ben előkerült négy sír egyikének leletanyagában szintén van két, még közöletlen csonthenger. Köszönetet mondunk Vida Tivadarnak, hogy felhívta a figyelmünket erre az adatra.

79 NAGY 1998, 176, Abb. 82:1a, Taf. 118: 14-15, Taf. 181:5-6.

80 Nagy 1998, 49, Taf. 43:18-19, Taf. 146:7, 10.

81 Trugly 1993, 195, Taf. IX. 6.

82 Kiss 1996, 127, Taf. 86:1.

83 Kiss 2001, 68, Taf. 42, 135:3, 5.

84 SALAMON - ERdÉly 1971, 27, Taf. 22:9.

85 Cs. Sós - Salamon 1995, 137, 152, PI. III, 13:4-5, PI. XV, 168:5.

86 BÁRDOS - GARAM 2009, 185, Taf. 162, 1406:19.

87 BÁRdOS - GARAm 2009, 20, 55, 67, 75, Taf. 8:4, 6, Taf. 39:15, 17, Taf. 51:23, 24, Taf. 63:13, 15.

88 BÂRZU 2010, Taf. 6. G. 19:4, Taf. 7, G. 27:7.

89 BÂRZU 2010, 178, Abb. 97.

90 BÂRZU 2010, 179, Abb. 100.

91 BÂRZU 2010, 130.

92 Szíjon vagy övön lévő gyűrű alakú tartozék, melybe a csatba kapcsolt szíj vagy öv végét bújtatják, hogy ne lógjon. Magyar Értelmező Kéziszótár, bújtató szócikk. 


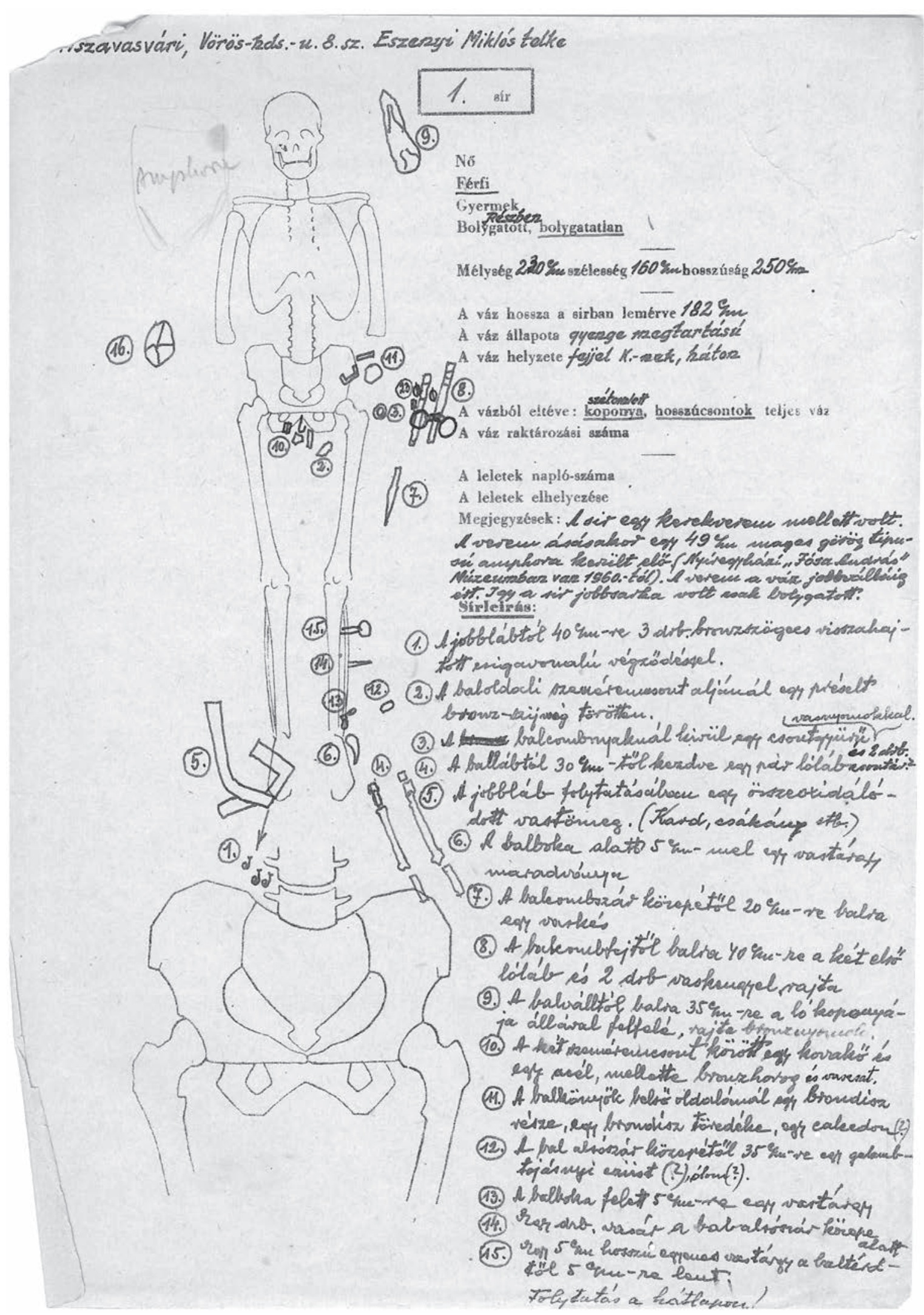

6. ábra. Gombás András leírása a sírról 


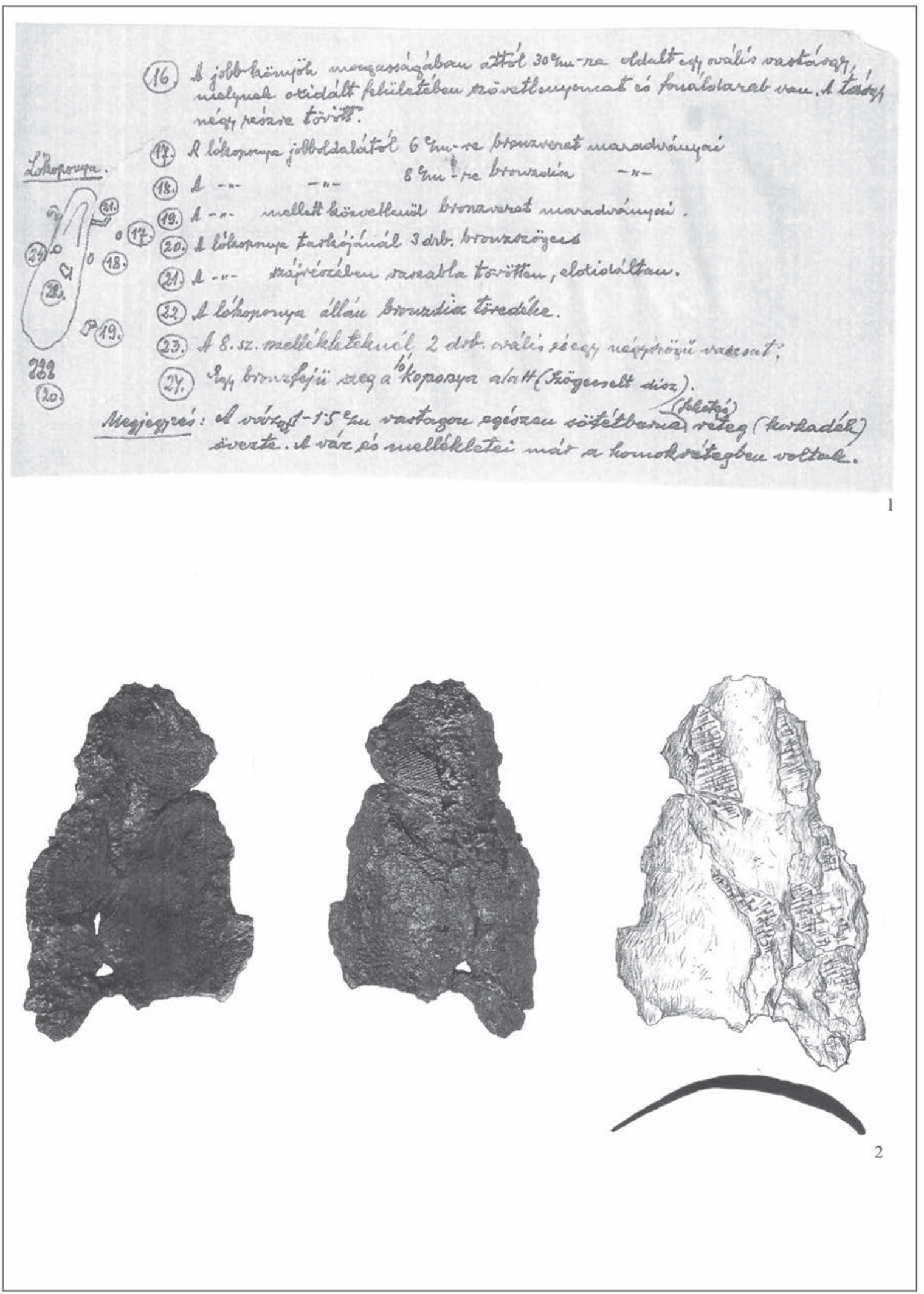

7. ábra. 1. Gombás András jegyzete. 2. Ivelt vastárgy a sírból 
A Tiszától keletre többségében részleges lótemetkezés mellől, addig a dunántúli temetőkben önálló lósírokból kerültek elő. A dunántúli példányok palástja faragással különböző mértékben díszített, a tiszántúliak díszítetlenek.

A csonthengerek használatának feltehetően voltak előzményei, melyek szerves anyagból (bőrből, fából) készülhettek. Viszont a kengyelszíj leszorításának egy ritka megoldását jelentette, amikor a vaskengyel fülén alakították ki ezt a funkciót. Példának említhetjük a mikebudai tausírozott kengyelfüleken lévő „szíjvédő pántokat".93 Müller Róbert a "mikebudaházi” kengyelpár lelőhelyének pontosítása során a kengyelfül kialakításának ezt a sajátosságát szíjszorítóként határozta meg, párhuzamként utalt a csengődi példányokra, valamint a szíjszorító funkció igazolására a cikói kengyelt említette, ahol a fülre rá van húzva a vaspánt.94

Vascsatok. A részleges lómaradványok környékén három darab került elő. Ezek közül két téglalap alakú darab a kengyelek környékén helyezkedett el, ezeket hevedercsatként értelmezhetjük, funkciójuk a kengyel magasságának szabályozása lehetett. A harmadik, a két mellső láb környékén előkerült darab valószínúleg a fejkantár nyitásával-zárásával függhetett össze.

Néhány megjegyzés a lószerszámzat sírbeli helyéről. Az adultus korú mén koponyája nem az állkapcsán, hanem a koponyatetőn feküdt. Ezért a felfordult lókoponya bal oldala mellől, az állkapocsról, illetve a tarkójánál kerültek elő az ezüstveretek töredékes állapotban, a felszerelő szegecsek és egy bronzpánt.

Mivel a vaszabla a ló állkapcsai között volt és a fejkantár vereteinek egy része a lókoponya bal oldalának közelében került elő, egyértelmúnek látszik, hogy a részlegesen eltemetett ló koponyáját felszerszámozták, azaz a temetés előtt ráhúzták a veretekkel díszített fejkantárt. Ezt igazolja, hogy a sírleírással és a sírrajzzal ellentétben az archaeozoológus a lócsontok vizsgálatai során a koponyacsontokon zöld patinafoltokat figyelt meg. ${ }^{95}$ A nyerget annak szerelékeivel és tartozékaival együtt a ló mellső két lába fölött fekvő lóbőrre helyezték.

A tarkó mögött fekvő három P alakú bronzszegeccsel megegyező formájú szegecsek kerültek elő a jobb lábfejtől 40 centiméterre. Ezek az előzőekkel együtt általában félgömb alakú, préselt ezüst lószerszámveretek felszerelő szegecsei. Ilyen félgömb alakú veret lehetett az a galambtojásnyi ezüsttöredék, amelyik a kitöltő masszával együtt a bal lábszár külső oldalától 35 centiméterre feküdt.

A nyereg vas szíjvezetője (4. ábra 4.) mindig a kengyelek és a hevedercsatok közelében kerül elő. Ebben a sírban viszont azoktól kb. egy méter távolságra, a bal lábszárcsont alsó vége felett feküdt. A fentiekben említett leletek sírbeli, másodlagos helyét együttesen csak úgy lehet értelmezni, hogy a lókoponya felől induló állatjárat elmozdította eredeti helyzetükből az ezüst lószerszámvereteket a szegecsekkel együtt, és a sír vége felé haladva a vas szíjvezetőt is kimozdította a kengyelek közeléből és a bal lábszárcsont mellé „vitte”.

\section{Viseleti tárgyak}

Vascsat. A két szeméremcsont között egy, az öv összefogására szolgáló vascsat helyezkedett el. A megvastagodott csatkeret és pecek germán - a Tiszántúl esetében gepida - hagyományokra vezethető vissza. A tárgy kora avar kori analógiáját a tágabb régióból Mokrin-Vodoplav-dülő 62. sírjából ismerjük. ${ }^{96}$

Veretes öv. A halott medencéje környékén ezüst övveretek maradványai kerültek elö. A rossz anyagmegtartásuk miatt csak egy bronz szíjvég maradt meg - ami azóta elveszett -, a többi veretre csak a felerősítő bronzpántok utalnak.

A Tiszántúl leggyakoribb övtípusát a díszítetlen szíjvégekkel ellátott, sok mellékszíjas övek jelentették, melyek kizárólag férfisírokban fordultak elő. Ezek ezüstből és bronzból egyaránt készülhettek. Tiszavasvári területéről még a koldusdombi temető 1. és 21. sírjából, ${ }^{77}$ míg a tágabb régióból Nyíregyháza-Városi kertészet 1936/3. sírból, Biharkeresztes-Lencséshátról, Hajdúdorog-Városkert út 1. sírból és Kaba-Belterületről ismertek veretes övek. ${ }^{98}$

93 DARNAY 1899, 278.

94 Müller 2006, 350. A csengődi és mikebudai kengyeleket lásd ERDÉlyı 1966, 56-57. kép, a Cikó 109. sír kengyele: SomoGyı 1984, 9. tábla 8. Mivel a kengyelfülnek ez a formai kialakítása csak néhány kora avar kori példányon található, ezért valószínűleg ez az „újítás” zsákutcásnak bizonyult, ezért nem másolták.

95 A ló koponyájának csak töredékei találhatók a múzeumi gyűjteményben. Ezek közül az orrcsont elején, a koponyatető közepén, az állkapocs jobb szárának külső szegleténél, valamint annak belső felületén, a hátsó fogak alatti részen láthatóak az ezüstveretek és a bronz felszerelő szegecsek zöldes lenyomatai.

96 Ranisavuev 2007, t. XXIV, 14.

97 CSALLÁNY 1960, 55, 58.

98 Garam 1992, 140; LöRinczy 2015, 161-162; Kralovánszky 1990, 120-122; Zoltai 1929. 


\section{Használati tárgyak}

Vaskések. Gombás András megfigyelései alapján a sírban két darab egyélű vaskés került elő, egyik a bal combcsontnál, a másik a két szeméremcsont között. Mivel az előbbi tárgy elveszett, a korrodált vastárgy késként való értelmezését nem tudjuk megerősíteni. Meg kell jegyeznünk azonban, hogy a kora avar kori Tiszántúlon nem lenne párhuzam nélküli a két kés sírba helyezése, amire példaként Óbesenyő (ma: Dudeştii Vechi, Románia) V. halom 2. és Szegvár-Oromdűlő 134. sírját lehet említeni. ${ }^{99}$ A megye területéről összesen kilenc sírból ismerünk vaskést, ezek egy kivételével - Nyíregyháza-Moszkva utca - tiszavasvári lelőhelyekről származnak. Férfi és női sírokban egyaránt előfordulnak, a legtöbb esetben az öv tájékán. ${ }^{100}$

Vaseszköz (szigony?). Külön szót érdemel az a villás vastárgy, ami a halott bal lábszárán került elő. Rekonstruált alakjából ítélve kézenfekvőnek tűnhet szigonyként való értelmezése. A kora avar kori szigonyok a 6-7. század kisszámú - és emiatt ritkán vizsgált - tárgytípusainak (1. táblázat) számát gyarapítja. Mivel mind gepida, mind langobard környezetben megtalálhatók, ezért hagyományosan germán tárgytípusként értelmezik. ${ }^{101}$

A Kárpát-medencéből ismert kora avar kori szigonyok eddig kivétel nélkül a Dunántúlról, férfisírokból kerültek elö. ${ }^{102} \mathrm{~A}$ szigonyos temetkezéseket Garam Éva halászok sírjaiként értelmezte, azonban a sírokban talált veretes övek alapján ezek a személyek nem voltak olyan szegények, mint amennyire a foglalkozás hallatán gondolhatnánk. ${ }^{103}$

A tiszavasvári fémszerszám szigonyként való értelmezése számos problémába ütközik. A töredékesen ránk maradt leletből, - amennyiben azt ténylegesen szigonyként akarjuk interpretálni - a formája alapján csak pár centiméter hiányozhat. A megmaradt 15,2 centiméteres hosszával is jóval kisebb, mint a legkisebb szigony (Zamárdi 2013. sír), így a méretadatok az ilyen irányú interpretálás ellen szólnak. A másik ellenérv a nyélhez való rögzítés kapcsán merült fel. A tiszavasvári fémtárgy egyágú vége nem köpüben végződik, hanem kör keresztmetszetű, vége elhegyesedő. Hasonló megoldás a ménfőcsanaki példányon megfigyelhető, így ez önmagában még nem zárja ki ezt az értelmezést. Garam Éva kiemelte, hogy a szigonyok nyéllel együtt kerültek a koporsóba, mégpedig úgy, hogy a vasfejük a lábfejek felé néz. ${ }^{104} \mathrm{Az}$ általunk vizsgált tárgy a bal lábszárcsontnál került elő, így a sírbeli helyzete - fanyél nélküli - szigonyként való értelmezését teszi lehetővé. Véleményünk szerint az itt felsorakoztatott érvek egy egyedi formájú és méretű - az elhunyt egy fiatal fiú volt - vasszigony mellett szólnak.

\begin{tabular}{|l|l|l|l|l|l|}
\hline \multicolumn{1}{|c|}{ Lelöhely-sírszám } & $\begin{array}{c}\text { Nyélre csatlakozás } \\
\text { módja }\end{array}$ & Ágak száma & $\begin{array}{l}\text { Szakák } \\
\text { állása }\end{array}$ & $\begin{array}{l}\text { Hossz } \\
(\sim) \text { cm }\end{array}$ & \multicolumn{1}{|c|}{ Irodalom } \\
\hline Kölked-Feketekapu A 21. sír & Gyürüvel & Háromágú & Befelé & 35 & Kiss 1996, 435, Taf 21, 4. \\
\hline Kölked-Feketekapu A 316. sír & Köpü nélkül & Kétágú & Befelé & 33 & Kiss 1996, 481, Taf. 67, 316/1. \\
\hline Kölked-Feketekapu A 324. sír & Köpüs(?) & Kétágú & Befelé & 34,4 & Kiss 1996, 482, Taf. 68, 324/12. \\
\hline Kölked-Feketekapu A 386 & Köpüs & Kétágú & Kifelé & 27,8 & Kiss 1996, 489, Taf. 75, 386/11. \\
\hline Kölked-Feketekapu B 80. sír & Gyürüvel & Háromágú & Befelé & 35 & Kiss 2001, 41, Taf 27, 2. \\
\hline Ménföcsanak-Bevásárlóközpont 552. sír & Köpü nélkül & Kétágú & Befelé & 24,8 & Tomka 2009, 255. \\
\hline Tiszavasvári, Eszenyi M. telke & Köpü nélkül & Kétágú(?) & - & $<15,5$ & \\
\hline Zamárdi-Réti földek 957. sír & Köpüs & Kétágú & Befelé & 32,1 & Garam 2009, 313, Taf. 111, 957/6. \\
\hline Zamárdi-Réti földek 977. sír & Köpüs & Kétágú & Befelé & 24,4 & Garam 2009, 314, Taf. 112, 977/17. \\
\hline Zamárdi-Réti földek 2013. sír & Köpüs & Kétágú & Befelé & 22 & Garam 2014, 195, Taf. 212, 2013/2. \\
\hline
\end{tabular}

1. táblázat. Avar kori vasszigonyok adatai

99 TÃNASE - GÁlL 2012, 700; LöRInCZY - StRAub 2004, 309.

100 LÖRINCZY - RÁCZ 2014, 179.

101 TOMKA 2009, 260

102 Garam 2014, 280.

103 Garam 2014, 280.

104 GARAM 2014, 280. 
Amfora. A mediterrán eredetű amforák az avar kor ritka tárgytípusai közé tartoznak, sírból összesen hat példány előkerüléséről van adatunk. Ezeket Vida Tivadar formai alapon négy csoportba sorolta, melyből a tiszavasvári darab az IF/b típusba tartozik. ${ }^{105} \mathrm{~A}$ témával újabban Csiky Gergely és Hárshegyi Piroska foglalkozott, akik a Kárpát-medencében előkerült példányokat a nemzetközi kutatásban használt - Vida Tivadar munkája után közel egy évtizeddel kidolgozott - tipológiai rendszerbe illesztették. A tiszavasvári amforát a LR1b típusba sorolták. ${ }^{106}$ Ez a kelet-mediterráneumi típus tágan a 6-7. századra keltezhető. Ebben az időszakban az amforák tömegesen fordultak elő a Fekete-tenger nyugati partvidékén és az Al-Duna melletti erődökben, az itt állomásozó katonák ellátását ugyanis Ciprusról származó borral oldották meg. ${ }^{107}$

Kelet-európai sírból egyedül az Izobel'noye-i példány ismert. A Krím északkeleti partvidékén található lelőhelyen egy korábbi halomba ásva egy magányos temetkezés került elö. A kard és a bronz övveretek tanúsága alapján egy férfi jobb lába mellett egy LR1a típusú amfora került előtt, mely alapján a sírt A. I. Ajbabin a 6. század végére, a 7. század első felére keltezte. ${ }^{108} \mathrm{~A}$ 7. század második felére keltezhető kultúrréteget nem, csak elszórt kerámiatöredékeket tartalmazó, nomád táborokként interpretált lelőhelyeken - például Čerednyky, Lavryky, Bilokoni, Poluzir'ya-2 - rendszeresen előkerültek amforák töredékei is. ${ }^{109}$ Bár a szaltovói telepeken viszonylag gyakran találnak amfora töredékeket, ${ }^{110}$ a $6-7$. századi kontextusban ritkán fordulnak elő.

Azonosithatatlan tárgy vasleletei. Nem lehet megkerülni a jobb lábfej csontjai előtt, illetve a külső oldala mellett előkerült két, nagyjából L alakú vastárgy említését. Funkciójukat nem lehet egyértelműen meghatározni, mivel maguk a tárgyak elvesztek. A sírlapon Gombás András által írt megnevezésük (kard, csákány?), több mint kétséges. Vele szemben Csallány Dezső - akinek volt kellő avar anyagismerete - az ásatási jelentésében ezekről a leletekről nem írt, miközben felsorolta az amfora mellett a rossz megtartású bronz öv- és lószerszámvereteket, zablát és a hosszúfülü kengyeleket is. A vasleletekről való hallgatására nem találunk magyarázatot.

Az L alakú tárgyak - a sírrajz alapján becsült - hosszabbik oldala kb. 20-25, a rövidebbik legalább 10-12, szélességük 5-6 centiméter lehetett. Azonosításuk során felmerülhet, hogy esetleg favödör vasalása, nyereg kápájának vasmerevítői, illetve vas lamella sorok lehettek. De valójában ezen lehetőségekkel szemben több a jogos ellenérv. Az tűnik csak valószínúnek, hogy az amforával és a nyaka alatt fekvő vastárggyal (7. ábra) együtt ezt az ismeretlen tárgyat is a koporsó padmalyba helyezése előtt tették a padmaly lábfelőli végébe.

Nem zárhatjuk ki annak lehetőségét, hogy a két, ma még meghatározhatatlan lelet (akár a feltételesen vasszigonyként értelmezett tárggyal együtt) összefügghet, és a jövőben újabb, szerencsésebb helyzetben előkerült párhuzamok alapján azonosíthatóak lesznek, ezért az Eszenyi-telki sír értelmezése és értékelése véglegesen csak akkor történhet meg.

\section{A sírban nyugvó egykori társadalmi és kronológiai helyzete}

Az általunk vizsgált sírban - ha hihetünk a hiányos adatokon nyugvó antropológiai meghatározásnak - egy juvenis korú fiút temettek. Fiatal kora ellenére a temetési rítus egyes elemei (magányos temetkezés, padmalyoshalmos sír, részleges lótemetkezés) és a sírba helyezett tárgyak (bizánci amfora, ezüst öv- és lószerszámveretek) egyaránt az elhunyt és családjának magas státuszára utalnak. Mivel írásos forrásaink nem maradtak fenn a kora avar kori tiszántúli népesség társadalmi berendezkedéséről, nem tudjuk biztosan eldönteni, hogy egy 15-16 éves fiú a közösségében már nagykorúnak számított-e. A Kashalmi-dúlő 33. és 34. sírjainak gazdag mellékletei - melyek semmiben sem különböztek a felnőttekre jellemző szettektől - arra engednek következtetni, hogy az itt eltemetett 12-14 éves fiatalok valószínúleg már nagykorúnak számítottak. ${ }^{11}$ Ugyanez vonatkozik Hajdúnánás-Fürjhalmi-dűlő 10. és 17. sírba temetettekre is. ${ }^{112}$

A megye területéről nem az amfora az egyetlen mediterrán jellegű lelet, mert a Kashalmi-dűlőben egy exagium és két Heraclius és Heraclius Constantinus solidusa, Nyíregyháza-Városi kertészet 1936/3. sírban egy Mauricus Tiberius solidus került elő. ${ }^{113}$

\footnotetext{
105 VIDA 1999, 90

106 CSIKY - MAGYAR-HÁRSHEGYI 2015, 177.

107 CSIKY - MAGYAR-HÁRSHEGYI 2015, 177-178.

108 AJBABIN 2011, 88.

109 KAZANSKI 2013, 802-804.

110 Pletneva 1967, 129-134.

111 LÖRINCZY - RÁCZ 2014, 181.

112 LÖRINCZY - RÁCZ 2014, 181.

113 LÖRINCZY - RÁCZ 2014, 187.
} 
Ezek valószínúleg nem közvetlenül a birodalom területéről, hanem a Maros-völgyéből, az új lakossággal érkeztek a területre. ${ }^{114} \mathrm{~A}$ régészeti adatok alapján meg lehetett állapítani, hogy a Köröstől északra fekvő tiszántúli területek a 6. század utolsó és a 7. század első harmadában ritkán lakottak voltak. Elképzelhető, hogy benépesedését a 626-os konstantinápolyi vereség utáni politikai instabilitás miatti belső népmozgások okozták, bár jelenleg e téren még csak találgathatunk. ${ }^{115}$

Az Eszenyi-telken feltárt sírban fellelt tárgytípusok túlnyomó többsége - az ezüst öv- és lószerszámveretek a rossz anyagmegtartásuk miatt meghatározhatatlan formájuk, típusuk miatt - nem bír pontosabb keltező értékkel, a kora avar koron belül nem lehet őket datálni. A tiszántúli kora avar kori temetkezésekben a kengyel megjelenését a kutatás hagyományosan későre, a 7. század első harmadára teszi. ${ }^{116} \mathrm{~A}$ lószerszámként előkerült, oválisra hajlított bronzpánt még az, melynek használatát a 7. század második negyedére valószínűsíthetjük, ${ }^{117}$ hasonlóan az amforához, amit a többi darabbal együtt a 7. század második negyedére kelteznek. ${ }^{118} \mathrm{Ez}$ nem mond ellent a fent vázolt történeti alapú datálásnak sem.

\section{A kora avar kori tiszántúli népesség Tiszavasvári határában}

Tiszavasvári határa avar kori lelőhelyekben rendkívül gazdag. Területén az összes kora avar kori temetőtípus képviselteti magát, magányos temetkezést (Eszenyi-telek), néhány síros szórt elrendezésű sírcsoportot (Kashalmidűlő) és - a tiszántúli viszonylatban - nagyobb sírszámú temetőt (Koldusdomb) egyaránt ismerünk. Ezek viszonylag közel fekszenek egymáshoz, az utóbbi két lelőhely között mindössze 800-1200 méter távolság van, míg az Eszenyi-telki sír a koldusdombi temetőtől 2,5 kilométerre helyezkedik el. ${ }^{19}$ Az avar kori emlékek nagy száma miatt nem véletlen, hogy Bóna István a település határába egy regionális települési „központot” képzelt. ${ }^{20}$ Lőrinczy Gábor és Rácz Zsófia a jelenséget a Tiszán való átkelési lehetőséggel magyarázta, ugyanis a lelőhelyek - a középkorban is használt - tiszalúci révhez vezető Hajdúdorog-Hajdúnánás-Tiszavasvári-Tiszadob útvonaltól 200-600 méter távolságra helyezkednek el. ${ }^{121}$ A település határából az avar kor második feléből is ismerünk lelőhelyeket, ${ }^{122}$ amelyek alapján a terület egészen a 9. századig biztosan lakott volt. Érdekesség, hogy az újonnan betelepülő közösségek mellett biztosan számolhatunk a kora avar kori lakosság továbbélésével, amire az Utasérpart-dülőben feltárt temetőrészlet sírjainak K-Ny-i tájolása, a padmalyos és a padkás sírforma megléte, a csonkolt részleges állatmaradványok, a juh keresztcsont és az edények sírba helyezése az archaikus temetkezési szokások közé tartoznak. ${ }^{123}$ De már a Petőfi utcai temető ${ }^{124}$ sírjaiból ismert részleges lótemetkezések fejlett változatával és a lószerszámos temetkezésekkel egy, a 7. század utolsó harmadában ide települt közösség nyughelye volt.

\section{Köszönetnyilvánítás}

Cikkünk nem készülhetett volna el a társtudományok múvelőinek és a Jósa András Múzeum munkatársainak segítsége nélkül. Köszönetet mondunk munkájáért Dankóné Németh Erika restaurátornak, a régészeti, antropológiai és archeozoológia leletek gondozásáért, napi kutatómunkánk segítéséért Mester Andrea gyűjteménykezelőnek, valamint sokirányú segítségért Istvánovits Eszternek. Az embertani meghatározást Marcsik Antóniának, az archeozoológiait Vörös Istvánnak, a textilvizsgálatért T. Knotik Mártának mondunk köszönetet. A tárgyrajzok Benke Zsolt grafikus, az illusztrációs táblák Pápai Zoltán munkáját dicsérik.

\section{Összefoglalás}

Cikkünkben a Tiszavasvári-Eszenyi-telek lelőhelyről származó magányos temetkezést mutattuk be. A leletegyüttes 1960-ban a település belterületéről került elő. Az ÉKK-DNyNy-i tájolású sír padmalyos kialakítású volt, az aknarészben egy felszerszámozott mén koponyája és lábcsontjai feküdtek. A padmalyban egy 15-16 év körüli, feltehetően férfi maradványai voltak. Ezek a temetkezési szokások a kora avar kori Tiszántúl nagy részén előfordultak és kelet-európai eredetre vezethetők vissza.

\footnotetext{
114 LöRINCZY 1998, 352; LóRINCZY - RÁCZ 2014, 187-188. Az, hogy az amfora a feltételezett dunai útvonalon történő megérkezése után (CSIKY - HÁRSHEGYI 2016, 33.) hogyan, mi módon kerülhetett a Tiszántúl déli részére, ma még megválaszolhatatlan kérdés.

115 LÖRINCZY - RÁCZ 2014, 189.

116 LöRINCZY 1998, 351.

117 LÖRINCZY - RÁCZ 2014, 161.

118 CSIKY - HÁRSHEGYI 2016, 31, 33.

119 LÖRINCZY - RÁCZ 2014, 186.

120 BónA 1986, 78. A kép túlzó voltáról: LöRINCZY - RÁCZ 2014, 186, 106. lj.

121 LÖRINCZY - RÁCZ 2014, 186.

122 LÖRINCZY 2002, 385-386.

123 ISTVÁNOVITS - LÖRINCZY 2017, 66.

124 FanCSALSZKY 1999, 110-122.
} 
Az elhunyt lábánál egy bizánci amfora helyezkedett el. Ez a régióban egyedülállónak számító darab a KeletMediterráneumban készülhetett és a 6-7. századra keltezhető. Az elemzésben különös figyelmet szenteltünk a ló maradványai között talált csont hengereknek, melyek a kengyel szíjazatát szorították le. A másik részletes bemutatott tárgytípus az $\Omega$ alakú vastárgy, mely a nyereg talpába vezetett szíj vezetésére szolgált. A férfi bal lábszárcsontjánál egy villás vastárgy helyezkedett el, amit a mérete alapján nem lehet egyértelmúen a szigonyok közé sorolni.

A 7. század első felében Tiszavasvári határából számos lelőhelyet ismerünk. Ezek között nagyobb sírszámú temetőket (Koldusdomb, Utas-éri-dűlő), temetési körzetet (Kashalmi-dűlő) és magányos sírt egyaránt (Eszenyitelek) megtalálható. A temetkezési szokások alapján az itteni lakosság valószínúleg a Maros-völgyében költöztek a régióba. A mellékletek közül számos tárgy a Bizánci Birodalommal való intenzív kapcsolat bizonyítékai. Jól illeszkedik ebbe a képbe a most bemutatott sír is. A temetkezési rítus bizonyos elemei (magányos temetkezés, padmalyos sír, részleges lovastemetkezés) valamint a mellékletek (bizánci amfora, ezüst öv-és lószerszámveretek) egyaránt az elhunyt magas státuszára utalnak.

\title{
Avar finds from Szabolcs-Szatmár Bereg county V. An Early Avar niche-grave from Tiszavasvári-Eszenyi-telek
}

\author{
BENCE GULYÁS - GÁBOR LŐRINCZY
}

In this article we examined the isolated grave from Tiszavasvári-Eszenyi-telek. These finds were found in 1960 in the residential area of the town. The niche grave was oriented to NEE-SWW, the skull and legs of a harnessed stallion were placed in the shaft. A cca. 15-16 year-old person, probably male, was buried in the niche. These burial customs were widespread in the Trans-Tisza region in the Early Avar period and they can be traced back to the East European steppe area.

Near the legs of the deceased, a Byzantine amphora was found, which does not have any analogy in the region. This vessel was made in the Eastern Mediterraneum presumably during the $6-7^{\text {th }}$ centuries. We paid special attention to the bone cylinders which were found among the horse bones. These were probably used for fixing the stirrups during riding. The other object we examined in detail is an omega shaped iron object, which was nailed into the saddle, probably used as a bridle-guide. Next to the tibia a forked iron object was found. Althrough it is similar in shape, it was definitely not a harpoon given its small size.

We know a lot of sites from the vicinity of Tiszavasvári, which can be dated to the first half of the $7^{\text {th }}$ century. Among these there are larger cemeteries (Koldusdomb, Utas-éri-dúlö), so-called burial areas with a few separated graves (Kashalmi-dúlö) and singular, isolated burials (Eszenyi-telek) as well. According to the specific burial customs, the population in question originated from the Maros valley. These graves contain numerous finds of Byzantine origin. The grave from Tiszavasvári-Eszenyi-telek fits well into this picture. Certain elements of the funeral rites (isolated grave, niche grave, horse remains) and the finds (the Byzantine amphora, silver mounts of the belt and the horse harness) refer to the high status of the deceased.

\section{Irodalom}

AdAm 2002 Szentpéteri, József (Hrsg.): Archäologische Denkmäler der Awarenzeit in Mitteleuropa. Varia Archaeologica Hungarica XIII. Budapest, 2002.

AJBABIN 2011 Ajbabin, Aleksandr I.: Archäologie und Geschichte der Krim in byzantinischer Zeit. Mainz, 2011.

AwAren 1985 Menghin, Walter - Kürti, Béla (Hrsg.): Awaren in Europa. Schätze eines asiatischen Reitervolkes 6.-8. Jh. Wien, 1986.

Avarok 1986 Kürti Béla (szerk.): Az avarok kincsei. Kiállításvezető. Budapest, 1986.

B. NAGY 2003 B. Nagy Katalin: A székkutas-kápolnadűlői avar temető. In: Bende Lívia - Lőrinczy Gábor (szerk.): B. Nagy Katalin: A székkutas-kápolnadülöi avar temető. Móra Ferenc Múzeum Évkönyve - Monographia Archaeologica 1. Szeged, 2003. 11-304.

BALOGH 2004 Balogh Csilla: Martinovka-típusú övgarnitúra Kecelről. A Kárpát-medencei maszkos veretek tipokronológiája (Gürtelgarnitur des Typs Martinovka von Kecel. Die Typochronologie der Maskenbeschläge des Karpetenbeckens). Móra Ferenc Múzeum Évkönyve - Studia Archaeologica 10. 241-304.

BALOGH 2016 Balogh Csilla: Régészeti adatok a Duna-Tisza közi avarok történetéhez (The history of the Avars in the DanubeTisza interfluve as reflected in the archaeological record). Studia ad Archaeolgiam Pazmaniensia. A PPKE BTK Régészeti Tanszékének kiadványai 6. Budapest, 2016.

BALOGH - GULYÁs - LŐRINCZY 2019 Balogh Csilla - Gulyás András - Lőrinczy Gábor: Újabb 7. századi temetkezések Békés megye területéről. 2019, s. a. 


\section{SZABOLCS-SZATMÁR-BEREG MEGYE AVAR SÍRLELETEI V. KORA AVAR KORI PADMALYOS TEMETKEZÉS TISZAVASVÁRI-ESZENYI-TELEKRŐL}

BÁRDos - GARAm 2009 Bárdos, Edith - Garam, Éva: Das awarenzeitliche Gräberfeld in Zamárdi-Rétiföldek. Teil I. Monumenta Archaeologica Avarorum Vol. 9. Budapest-Kaposvár, 2009.

BÁRDos - Garam 2014 Bárdos, Edith - Garam, Éva: Das awarenzeitliche Gräberfeld in Zamárdi-Rétiföldek. Teil II. Monumenta Archaeologica Avarorum Vol. 10. Budapest, 2014.

BÂrzu 2010 Bârzu, Ligia: Ein gepidisches Denkmal aus Siebenbürgen. Das Gräberfeld 3 von Bratei. Cluj-Napoca, 2010.

BENDE 2000 Bende Lívia: Fülkesírok a pitvarosi avar kori temetőben. Adatok a fülkés és lószerszámos temetkezések kronológiájához (Stollengräber im awarenzeitlichen Gräberfeld von Pitvaros. Angaben zur Chronologie der Stollengräber und Bestattungen mit Pferdegeschirr). In: Bende Lívia - Lőrinczy Gábor - Szalontai Csaba (szerk.): Hadak útján. A népvándorlás kor fiatal kutatóinak 10. konferenciája. Szeged, 2000. 241-279.

Bende 2012 Bende Lívia: Lószerszámos temetkezések, áldozati állatok és ételmellékletek a Körös-Tisza-Maros köze késő avar kori temetőiben (Bestattungen mit Pferdegeschirr, Tieropfer und Speisebeigaben in den späawarezeitlichen Gräberfeldern des Gebietes zwischen Kreisch/Körös, Theiß/Tisza und Mieresch/Maros). In: Vida Tivadar (szerk.): Thesaurus Avarorum. Régészeti tanulmányok Garam Éva tiszteletére. Budapest, 2012. 645-678.

BENDE 2017 Bende Lívia: Temetkezési szokások a Körös-Tisza-Maros közén az avar kor második felében (Bestattungsbräuche in der zweiten Hälfte der Awarenzeit im Gebiet zwischen Körös, Theiß und Maros). Studia ad Archaeolgiam Pazmaniensia. A PPKE BTK Régészeti Tanszékének kiadványai 8. Budapest, 2017.

BónA 1986 Bóna István: Szabolcs-Szatmár megye régészeti emlékei 1. In: Entz Géza (szerk.): Szabolcs-Szatmár megye müemlékei 1. Magyarország műemléki topográfiája 10. Budapest, 1986. 15-91.

BöKÖNYI 1974 Bökönyi, Sándor: History of domestic mammals in Central and Eastern Europe. Budapest, 1974.

Cs. Sós - Salamon 1995 Cs. Sós, Ágnes - Salamon, Ágnes: Cemeteries of the Early Middle Ages (6-9 ${ }^{\text {th }}$ C.) at Pókaszepetk. Budapest, 1995.

CSALLÁNY 1939 Csallány Gábor: A szentes-derekegyházi népvándorláskori sírlelet (Der völkerwanderungszeitliche Grabfund von Szentes-Derekegyháza). Folia Archaeologica 1-2. 116-120.

Csallány 1960 Csallány Dezső: Szabolcs-Szatmár megye avar leletei (Awarische Funde des Komitats Szabolcs-Szatmár). Jósa András Múzeum Évkönyve 1. 31-85.

CSIKY - HÁRSHEGY 2016 Csiky Gergely - Hárshegyi Piroska: Kereskedelem vagy ajándék? Amphorák az avar kori Kárpátmedencében (Trade or gift? Amphorae from Avar Period burials in the Carpathian Basin). In: S. Perémi Ágota (szerk.): A népvándorláskor fiatal kutatóinak 23. konferenciája. Veszprém, 2016. 27-37.

CSIKY - MAGYAR-HÁRSHEGYI 2015 Csiky, Gergely - Magyar-Hárshegyi, Piroska:Wine for the Avar elite? Amphorae from Avar period burialsintheCarpathian Basin.In:Tsetskhladze, Gocha R.-Avram, Alexandru-Hargrave,James(eds.):TheDanubianLands between the Black, Aegean and Adriatic Seas ( $7^{\text {th }}$ Century BC $-10^{\text {th }}$ Century AD) Proceedings of the Fifth International Congress on Black Sea Antiquities (Belgrade, 17-21 September 2013). Oxford, 2015. 175-182.

DARNAY 1899 Darnay Kálmán: A Zala-Szántói halmok és két magyar lovas-sír. Archaeologiai Értesítő 19. 277-280.

ERDÉLYI 1966 Erdélyi István: Avar müvészet. Budapest, 1966.

FANCSALSZkY 1999. Fancsalszky Gábor: Három avar kori temető Tiszavasváriban (Drei awarenzeitlichen Gräberfelder von Tiszavasvári). Communicationes Archaeologicae Hungariae 1999. 107-141.

GARAM 1992 Garam, Éva:Die münzdatierten Gräber der Awarenzeit. In: Falko Daim (Hrsg.): Awarenforschungen 1. Archaeologia Austriaca Monographien 1-2. Studien zur Archäologie der Awaren 4. Wien, 1992. 135-250.

GARAM 2014 Garam Éva: Egy avar kori falu gazdálkodásáról, kézművességéről, életmódjáról a falu temetője sírjaiban talált tárgyak tükrében (The economy, the craft industry and the life-style of an Avar period village in the light of the grave goods from the village cemetery). In: Anders Alexandra - Balogh Csilla - Türk Attila (szerk.): Avarok pusztái. Tanulmányok Lőrinczy Gábor 60. születésnapjára. Budapest, 2014. 279-290.

GuLYÁs 2013 Gulyás Bence: Kora avar kori magányos temetkezések és szórványsírok a Tiszántúlon. ELTE BTK, Alapszakos szakdolgozat. Kézirat, Budapest, 2013.

GulyÁs - LöRINCZY 2018 Gulyás Bence - Lőrinczy Gábor: Szabolcs-Szatmár-Bereg megye avar sírleletei IV. A tiszavasvárikoldusdombi kora avar kori temető domb). In: L. Nagy Márta - L. Szőlősi Katalin(szerk.): „Vadrózsából tündérsípot csináltam.” Tanulmányok Istvánovits Eszter 60. születésnapjára. A Jósa András Múzeum Kiadványai 73. Nyíregyháza, 2018. 529-570.

H. TótH - Horvátr 1992 H. Tóth, Elvira - Horváth, Attila: Kunbábony, das Grab eines Awarenkhagans. Kecskemét, 1992.

IsTVÁNOVITS 1991 Istvánovits Eszter: Adatok a Felső-Tisza-vidék 4-5. századi történetéhez a tiszadobi temető alapján (Beiträge zur Geschichte des oberen Theißgebiets in dem 4-5. Jahrhundert). A Móra Ferenc Múzeum Évkönyve 1984/85-2. (1991) 29-53. 
IstVÁNOVITS - LőRINCZY 2017 Istvánovits Eszter - Lőrinczy Gábor: Avar temető és teleprészlet Nyíregyháza és Tiszavasvári határából. Szabolcs-Szatmár-Bereg megye avar sírleletei III. (Avarian Age cemetery and settlement parts from the vicinities of Tiszavasvári and Nyíregyháza. Avarian finds of Szabolcs-Szatmár-Bereg County III.). Jósa András Múzeum Évkönyve 59. 35-178.

JuHÁsz 1995 Juhász, Irén: Awarenzeitliche Gräberfelder in der Gemarkung Orosháza. Monumenta Avarorum Archaeologica Vol. 1. Budapest, 1995.

JuHÁsz 2004 Juhász, Irén: Das awarenzeitliche Gräberfeld in Szarvas-Grexa-téglagyár. FO 68. Monumenta Avarorum Archaeologica Vol. 7. Budapest, 2004.

KAZANSKı 2013 Kazanski, Michael: The Middle Dnieper area in the seventh century: an archaeological survey. Travaux et Mémoires 17. 769-864.

Kıss 1996 Kiss, Attila: Das awarenzeitlich gepidische Gräberfeld von Kölked-Feketekapu A. Monographien zur Frühgeschichte und Mittelalterarchäologie 2. Studien zur Archäologie der Awaren 5. Innsbruck, 1996.

Kıss 2001 Kiss, Attila: Das awarenzeitliche Gräberfeld in Kölked-Feketekapu B. Monumenta Avarorum Archaeologica Vol. 6. Budapest, 2001.

KRALOVÁnszky 1990 Kralovánszky Alán: A hajdúdorogi VII. századi avar temető (előzetes ismertetés) (A $7^{\text {th }}$ Century Avar Cemetery from Hajdúdorog (preliminary report)). Debreceni Déri Múzeum Évkönyve 1989-90. (1992) 117-139.

LÁszló 1976 László Gyula: A bócsai fejedelmi sír és a keceli kard. Cumania 4. 89-114.

LÁszló 2017 László Gyula: A csákberény-orondpusztai avar kori temető. (Szerk.: Szentpéteri József) Székesfehérvár, 2017.

LENGYEL 1960 Lengyel Irina:Tiszavasvári. Régészeti Füzetek Ser. I/13. 31.

LENGYeL 1960a Lengyel Irina:Tiszavasvári. Régészeti Füzetek Ser. I/14. 20.

LŐRINCZY 1992 Lőrinczy, Gábor: Vorläufiger Bericht über die Freilegung des Gräberfeldes aus dem 6.-7. Jahrhundert in Szegvár-Oromdűlő. Weitere Daten zur Interpretierung und Bewertung der partiellen Tierbestattungen in der frühen Awarenzeit. Communicationes Archaeologicae Hungariae 1992. 81-124.

LőRINCZY 1996 Lőrinczy Gábor: Kora avar kori sír Szentes-Borbásföldről (Ein frühawarenzeitliches Grab in Szentes-Borbásföld). A Móra Ferenc Múzeum Évkönyve - Studia Archaeologica 2. 177-190.

LŐRINCZY 1998 Lőrinczy Gábor: Kelet-európai steppei népesség a 6-7. századi Kárpát-medencében. Régészeti adatok a Tiszántúl kora avar kori betelepüléséhez (Osteuropäische Steppenbevölkerung im 6. und 7. Jahrhundert im Karpatenbecken. Archäologische Beiträge zur frühawarenzeitlichen Einsiedlung des Gebietes jenseits der Theiß). A Móra Ferenc Múzeum Évkönyve - Studia Archaeologica 4. 343-372.

LŐRINCZY 2002 Lőrinczy, Gábor: Tiszavasvári-Büdi kenderföld, Tiszavasvári-Dózsa telep, Tiszavasvári-Petőfi út, TiszavasváriTéglagyár, Tiszavasvári-Városföldje, Tiszavasvári-Zöld Mező tsz. In: ADAM 2002, 385-386.

LŐRINCZY 2015 Lőrinczy Gábor: Újabb adatok Hajdú-Bihar megye avar kori lelőhelyeihez I. Megjegyzések a terület kora avar kori történetéhez (New data on the Avarian Age sites of Hajdú-Bihar County I. Some notes on the Early Avarian Age history of the region). Jósa András Múzeum Évkönyve 57. 149-176.

LőrINCZY 2016 Lőrinczy Gábor: A tiszántúli VI-VII. századi sírok és temetők sajátosságai. A kora avar kori népesség továbbélése a VII-IX. században a Körös-Tisza-Maros közén (Characteristic features of $6^{\text {th }}-7^{\text {th }}$ century burials and cemeteries east of the Tisza. Survival of Early Avarian Age population between Rivers Körös, Tisza and Maros). Jósa András Múzeum Évkönyve 58. 155-176.

LőRINCZY 2017 Lőrinczy, Gábor: Frühawarenzeitliche Bestattungssitten im Gebiet der Grossen Ungarischen Tiefebene östlich der Theiss. Archäologische Angaben und Bemerkungen zur Geschichte der Region im 6. und 7. Jahrhundert. Acta Archaeologica Hungaricae 68. 137-170.

LŐRINCZY - RACZ 2014 Lőrinczy Gábor - Rácz Zsófia: Szabolcs-Szatmár-Bereg megye avar sírleletei II. Tiszavasvári-Kashalomdűlő kora avar kori temetkezései (Avarian finds from Szabolcs-Szatmár-Bereg County II. Early Avarian graves from Tiszavasvári-Kashalom-dűlö). Jósa András Múzeum Évkönyve 56. 141-217.

LŐRINCZY - Straub 2004 Lőrinczy Gábor - Straub Péter: Újabb adatok az avar kori szűrőkanalak értékeléséhez II. (Neue Angaben zur Bewertung der awarenzeitlichen Sieblöffel II.). A Móra Ferenc Múzeum Évkönyve - Studia Archaeologica 10. 305-337.

Lő́RINCZY - StRAUB 2005 Lőrinczy Gábor - Straub Péter: Alpi típusú övgarnitúra a szegvár-oromdűlői 81. sírból (Alpine-type set from Szegvár-Oromdűlő, grave 81.). Zalai Múzeum 14. 137-167.

LöRINCZy - StRAub 2006 Lőrinczy Gábor - Straub Péter: Az avar kori padmalyos temetkezésekről. Szempontok a Kárpátmedencei padmalyos temetkezések értékeléséhez (Über die awarenzeitlichen Nischengräber. Angaben zur Bewertung der Nischengräber des Karpatenbeckens). Arrabona 44/1. 279-316. 


\section{KORA AVAR KORI PADMALYOS TEMETKEZÉS TISZAVASVÁRI-ESZENYI-TELEKRŐL}

LŐRINCZY - SZALONTAI 1996 Lőrinczy Gábor - Szalontai Csaba: Újabb régészeti adatok Csongrád megye területének 6-11. századi településtörténetéhez II. (Neuere archäologische Angaben zur Siedlungsgeschichte des Komitates Csongrád vom 6. bis 11. Jahrhundert. II.). A Móra Ferenc Múzeum Évkönyve - Studia Archaeologica 2. 269-298.

Madaras 2002 Madaras, László: Tiszaderzs-Szentimrei út. In: AdAm 2002, 378.

MESTERHAZY 1987 Mesterházy Károly: Korai avar részleges lovastemetkezések Ártándról és Biharkeresztesről (Frühawarische partielle Pferdebestattungen aus Ártánd und Biharkereszte). Folia Archaeologica 38. 219-245.

MülLER 2006 Müller Róbert: A mikebudai avar kengyelpár (Awarische steigbügelpaar von Mikebuda). Arrabona 2006. 349-356.

NAGY 1998 Nagy, Margit: Awarenzeitliche Gräberfelder im Stadtgebiet von Budapest I-II. Budapest, 1998.

PLetneVA 1967 Светлана, Александровна Плетнёва: От кочевий к городам. Материалы и Исследования по археологии СССР 142. (отв. ред. Б. А. Рыбаков). Москва, 1967.

RANISAVLJEv 2007 Ranisavljev, Alesandar: Ranosrednjovekovna nekropola kod Mokrina (Early Medieval necropolis near Mokrin). Glasnik Srpskog arheološkog društva 23. Beograd, 2007.

SALAMON - ERDÉlYI 1971 Salamon, Ágnes - Erdélyi, István: Das völkerwanderungszeitliche Gräberfeld von Környe. Studia Archaeologica 5. Budapest, 1971.

Somogy 1984 Somogyi Péter: A cikói temető. Das Gräberfeld von Cikó. In: Kiss Gábor - Somogyi Péter: Tolna megyei avar temetök. Dissertationes Pannonicae Ser. III/2. Budapest, 1984. 37-102.

Somogy 1997 Somogyi, Péter: Drei frühawarenzeitliche Bestattungen aus der Fundstelle Nr. 264 von Gyoma (Három kora avar kori sír a Gyoma 264. sz. lelőhelyről). A Móra Ferenc Múzeum Évkönyve - Studia Archaeologica 3. 97-116.

TĂNASE - GÁl 2012 Tănase, Daniela - Gáll, Erwin: Von Kisléghi Nagy Gyula bei Dudeştii Vechi entdeckte Gräber aus der Awarenzeit - der Hügel V. In: Vida Tivadar (szerk.): Thesaurus Avarorum. Régészeti tanulmányok Garam Éva tiszteletére. Budapest, 2012.697-706.

Томка 2005 Tomka Péter: Korai avar sírok Börcs-Nagydombon (Győr-Moson-Sopron megye) (Frühawarenzeitliche Gräber in Börcs-Nagydomb [Kom. Győr-Moson-Sopron]). Archaeologiai Értesítő 130. 137-180.

Томка 2008 Tomka, Péter: Die Lehre der Bestattungsbräuche. Antaeus 29-30. 233-263.

Томка 2009 Tomka Péter: Ménfőcsanak-Bevásárlóközpont (Metro) 552. sír - a „lovashalász” avagy az interpretáció határai (Ménfőcsanak-Einkaufszentrum (Metro), Grab 552 - Der "berittene Fischer” oder die Grenzen der Interpretation). In: Somogyvári Ágnes - V. Székely György (szerk.): „In terra quondam Avarorum...” Ünnepi tanulmányok H. Tóth Elvira 80. születésnapjára. Archaeologica Cumanica 2. Kecskemét, 2009. 253-270.

TRUgly 1993 Trugly, Alexander: Gräberfeld aus der Zeit des awarischen Reiches bei der Schiffswerft in Komárno II (19871989). Slovenská archeológia 41. 191-307.

VIDA 1999 Vida, Tivadar: Die awarenzeitliche Keramik I. Varia Archaeologica Hungarica 8. Budapest, 1999.

VöRös 2002 Vörös István: Áldozatiállat-maradványok a tótkomlósi avar kori sírban (Reste von Opfertieren im awarenzeitlichen Grab von Tótkomlós). A Móra Ferenc Múzeum Évkönyve - Studia Archaeologica 8. 345-350.

ZoltAl 1929 Zoltai Lajos: Régészeti ásatásaink 1928-ban Kabán: egy hun-avarkori lovas sír. Jelentés Debrecen szab. kir. város múzeumának és közművelődési könyvtárának 1928. évi működéséről 23. 38-40, 52. 
